\title{
Microbial Community Evolution and Fate of Antibiotic Resistance Genes along Six Different Full-Scale Municipal Wastewater Treatment Processes
}

Tong, Juan; Tang, Anping; Wang, Hongyan; Huang, Zhaohua; Wang, Ziyue; Zhang, Junya; Wei, Yuansong; Su, Yanyan; Zhang, Yifeng

Published in:

Bioresource Technology

Link to article, DOI:

10.1016/j.biortech.2018.10.079

Publication date:

2019

Document Version

Peer reviewed version

Link back to DTU Orbit

Citation (APA):

Tong, J., Tang, A., Wang, H., Huang, Z., Wang, Z., Zhang, J., Wei, Y., Su, Y., \& Zhang, Y. (2019). Microbial Community Evolution and Fate of Antibiotic Resistance Genes along Six Different Full-Scale Municipal Wastewater Treatment Processes. Bioresource Technology, 272, 489-500.

https://doi.org/10.1016/j.biortech.2018.10.079

\section{General rights}

Copyright and moral rights for the publications made accessible in the public portal are retained by the authors and/or other copyright owners and it is a condition of accessing publications that users recognise and abide by the legal requirements associated with these rights.

- Users may download and print one copy of any publication from the public portal for the purpose of private study or research.

- You may not further distribute the material or use it for any profit-making activity or commercial gain

- You may freely distribute the URL identifying the publication in the public portal 


\section{Accepted Manuscript}

Microbial Community Evolution and Fate of Antibiotic Resistance Genes along Six Different Full-Scale Municipal Wastewater Treatment Processes

Juan Tong, Anping Tang, Hongyan Wang, Xingxin Liu, Zhaohua Huang, Ziyue Wang, Junya Zhang, Yuansong Wei, Yanyan Su, Yifeng Zhang

PII: S0960-8524(18)31511-6

DOI: https://doi.org/10.1016/j.biortech.2018.10.079

Reference: BITE 20643

To appear in: Bioresource Technology

Received Date: 29 September 2018

Revised Date: 23 October 2018

Accepted Date: 26 October 2018

Please cite this article as: Tong, J., Tang, A., Wang, H., Liu, X., Huang, Z., Wang, Z., Zhang, J., Wei, Y., Su, Y., Zhang, Y., Microbial Community Evolution and Fate of Antibiotic Resistance Genes along Six Different Full-Scale Municipal Wastewater Treatment Processes, Bioresource Technology (2018), doi: https://doi.org/10.1016/ j.biortech.2018.10.079

This is a PDF file of an unedited manuscript that has been accepted for publication. As a service to our customers we are providing this early version of the manuscript. The manuscript will undergo copyediting, typesetting, and review of the resulting proof before it is published in its final form. Please note that during the production process errors may be discovered which could affect the content, and all legal disclaimers that apply to the journal pertain. 


\section{Microbial Community Evolution and Fate of Antibiotic Resistance Genes}

\section{along Six Different Full-Scale Municipal Wastewater Treatment}

\section{Processes}

Juan Tong ${ }^{1,2} \cdot$ Anping Tang ${ }^{2} \cdot$ Hongyan Wang ${ }^{2} \cdot$ Xingxin $\mathrm{Liu}^{2} \cdot$ Zhaohua Huang $^{2} \cdot$ Ziyue Wang $^{2} \cdot$ Junya Zhang $^{1,2}$. Yuansong Wei ${ }^{1,2 *}$. Yanyan $\mathrm{Su}^{3}$. Yifeng Zhang ${ }^{4}$

1. State Key Joint Laboratory of Environmental Simulation and Pollution Control,

Research Center for Eco-Environmental Sciences, Chinese Academy of Sciences, Beijing 100085, China

2. Department of Water Pollution Control, Research Center for Eco-Environmental Sciences, Chinese Academy of Sciences, Beijing 100085, China

3. Carlsberg Research Laboratory, J.C. Jacobsens Gade 4, DK-1799 Copenhagen V, Denmark

4. Department of Environmental Engineering, Technical University of Denmark, Copenhagen Lyngby 2800, Denmark

\section{Corresponding Author}

Yuansong Wei*, Email: yswei@rcees.ac.cn 


\section{Abstract}

The evolution of microbial community and the fate of ARGs along different full-scale wastewater treatment processes (i.e., Anaerobic-Anoxic-Oxic, Oxidation Ditch, and Cyclic Activated Sludge System) were investigated in this study. We found that the sludges of bioreactors treating similar influent showed the similar microbial communities, independent of the treatment technologies. The horizontal gene transfer (HGT) mainly occurred in aeration tank rather that anaerobic/anoxic tank. More co-occurrence of potential pathogens and ARGs was found in wastewater than in sludge. Microbial biomass was the key driver for the fate of ARGs in wastewater, while mobile genetic elements (MGEs) was the key factor for the fate of ARGs in sludge. Combination of wastewater characteristics, microbial diversity, microbial biomass, and MGEs contributed to the variation of ARGs. Finally, it was found that enhanced nutrients removal process and tertiary treatment would benefit ARGs removal.

Keywords: Antibiotic resistance genes; Microbial community evolution; Full-scale wastewater treatment plant; Network analysis; Multiple linear regression

\section{Introduction}

Antibiotics resistance as emerging contaminants in the environment has been receiving increasing concern due to their possible threats to human health. Wastewater treatment plants (WWTPs) are an important reservoir of antibiotic resistance bacteria (ARB) and associated antibiotic resistance genes (ARGs) (Ju et al., 2016; Pruden, 2013). Therefore, a better understanding of the occurrence and the fate of ARGs, and the mechanisms that 
contribute to the emergence and spread of antibiotic resistance in full-scale WWTPs is required.

The prevalence of ARGs in influents and effluents (Bengtsson-Palme et al., 2016; Karkman et al., 2016; Makowska et al., 2016; Rafraf et al., 2016), and activated sludge (Sun et al., 2016; Wei et al., 2018; Zhang et al., 2016) of full-scale municipal WWTPs have been intensively investigated. Some researchers found that the full-scale WWTPs could efficiently reduce the ARGs (An et al., 2018; Karkman et al., 2016), whereas other researchers found the opposite (Rafraf et al., 2016). Although the distribution of different ARGs in WWTPs has been investigated, there is still a lack of comprehensive understanding of the correlation between the fate of ARGs and different wastewater treatment processes. It is believed that most of the ARGs in the influent are mainly transferred to activated sludge in WWTPs (Yang et al., 2014), while the influences of bacterial communities on ARGs and the interaction between them are still unclear. Furthermore, bacterial community shifts have been reported as the major driver to shape the ARGs (Chen et al., 2016; Zheng et al., 2017). Therefore, it is important to understand the evolution of the microbial community in the WWTPs. Besides, the microbial community of the influent (Lee et al., 2015; McLellan et al., 2010; VandeWalle et al., 2012) and the activated sludge (Fan et al., 2017; Fan et al., 2018; Lee et al., 2015) of the full-scale WWTPs have been investigated. However, further investigation and comparison of the evolution of microbial community composition and the variation of microbial diversity along different wastewater treatment processes are needed. Besides, it is also 
necessary to find out the co-occurrence of the ARGs and the potential host especially for the potential pathogens. In addition to the microbial community, the mobile genetic elements (MGEs) (Guo et al., 2017) and the wastewater characteristics including COD (Yuan et al., 2015), pH (Huang et al., 2017), conductivity (Koczura et al., 2016), ammonia (Guo et al., 2015), may also affect the fate of ARGs in wastewater. However, due to numerous factors contribute to the variations of ARGs in a complex interplay, how would these factors impact ARGs in wastewater treatment remains a black box (Manaia et al., 2018).

Among various wastewater treatment processes, Anaerobic-Anoxic-Oxic $\left(\mathrm{A}^{2} / \mathrm{O}\right)$, Oxidation Ditch (OD), and Cyclic Activated Sludge System (CASS) are the most popular processes adopted by municipal WWTPs in China. The fate of ARGs and evolution of the microbial community along these treatment processes have never been compared.

Therefore, the purpose of this study is to elaborate on the evolution of the microbial community and the fate of ARGs in wastewater and sludge along $\mathrm{A}^{2} / \mathrm{O}, \mathrm{OD}$, and CASS process, and then to identify the key factors (e.g., wastewater characteristics, microbial biomass, MGEs, microbial diversity, and microbial community) associated with the fate of ARGs. In addition, the co-occurrence of ARGs and host bacteria including potential pathogens in the wastewater treatment systems were also investigated. This work could provide further information on the fate of ARGs in full-scale WWTPs running with different treatment technologies, and then offer insight into better control of ARGs spreading from the WWTPs. 


\section{Materials and methods}

\subsection{Sample collection}

Six WWTPs with three different treatment processes in Hebei province, China were investigated, i.e. plant A and B using CASS; plant C and D using Orbal OD, plant E and F using $\mathrm{A}^{2} / \mathrm{O}$. Domestic sewage was predominant influent of plant $\mathrm{A}, \mathrm{B}, \mathrm{C}$, and $\mathrm{D}$, with average flow rates ranging from 8,000 to $10,000 \mathrm{~m}^{3} / \mathrm{d}$. The influent of plant $\mathrm{E}(100,000$ $\left.\mathrm{m}^{3} / \mathrm{d}\right)$ was mainly domestic wastewater, whereas influent of plant $\mathrm{F}\left(100,000 \mathrm{~m}^{3} / \mathrm{d}\right)$ was $60 \%$ industrial wastewater (mainly treated coking wastewater and steel industrial wastewater) and $40 \%$ domestic wastewater. The oxic tank of plant $\mathrm{E}$ was moving bed biofilm reactor (MBBR), whereas oxic tank of plant $\mathrm{F}$ was activated sludge process. The secondary effluents of plant $\mathrm{E}$ and $\mathrm{F}$ were disinfected by chlorine. Only plant $\mathrm{E}$ and $\mathrm{F}$ have a tertiary treatment process. The tertiary treatment of plant $\mathrm{E}$ are mechanical stirring clarifier process with lime addition to remove the hardness, followed by neutralization with sulfuric acid, and then the continuous sand filter for further remove suspended solids. Tertiary treatment of plant F is Densadeg Clarifier (tertiary settling) followed by cloth filter. The wastewater treatment processes and sampling locations of WWTPs are shown in

Figure 1. Specifically, the samples from bio-treatment tanks were sludge samples. Three independent sampling events from each WWTP were conducted from January to July in 2017. The detail operational parameters of WWTPs were not available. The samples of CASS bio-selection tank of plant A were not obtained due to logistic issues, but it doesn't affect the main findings in this work. 


\subsection{Analytical methods for wastewater and sludge characterization}

All samples were kept on the ice and transported to the laboratory for pretreatment within $24 \mathrm{~h}$. The wastewater samples were filtered through $0.22 \mu \mathrm{m}$ polyvinylidene fluoride membranes (Millipore, USA), whereas the sludge samples were filtered through $0.45 \mu \mathrm{m}$ cellulose membrane (Millipore, USA). Then the filtrates were used to measure the characteristics in terms of alkalinity (ALK), conductivity, $\mathrm{COD}, \mathrm{NH}_{4}^{+}-\mathrm{N}, \mathrm{NO}_{2}^{-}-\mathrm{N}$, $\mathrm{NO}_{3}{ }^{-}-\mathrm{N}$, and $\mathrm{PO}_{4}{ }^{3-}-\mathrm{P}$, according to the standard method (APHA, 2005). The $\mathrm{pH}$ was determined using a pH meter (pHs-3C, Leici, China). The sum of $\mathrm{NH}_{4}{ }^{+}-\mathrm{N}, \mathrm{NO}_{2}^{-}-\mathrm{N}$, and $\mathrm{NO}_{3}{ }^{-}-\mathrm{N}$ concentration was recorded as total inorganic nitrogen (TN). In addition, the mixed liquor suspended solids (MLSS) and mixed liquor volatile suspended solids (MLVSS) of sludge samples were detected following the standard method for calculating the abundance of ARGs in sludge. The wastewater characteristics are shown in Table 1.

\subsection{DNA extraction and quantification by qPCR}

Each wastewater sample of 1-300 mL was filtered through $0.22 \mu \mathrm{m}$ sterile polyvinylidene fluoride membranes, and then the membranes were cut into pieces with pre-sterilized scissors and subjected to DNA extraction. $0.5 \mathrm{~mL}$ of each sludge sample from bioreaction system were used to extract DNA. All DNA extractions were performed with Fast DNA SPIN kit for soil (MP-bio, USA). The concentration and quality of the extracted DNA were determined by NanoDrop 2000 (Thermo Scientific, USA) and agarose gel electrophoresis, respectively. The following targets were measured in this study: Extended-spectrum beta-lactamases (ESBLs) genes bla $a_{\mathrm{TEM}}$ and $b l_{\mathrm{CTX}-\mathrm{M}}$; 
Macrolide-Lincosamide-Streptogramin (MLS) resistance genes erm $\mathrm{B}$, erm $\mathrm{F}$, mef $\mathrm{A} / \mathrm{E}$;

fluoroquinolone resistance genes $q n r \mathrm{~A}, q n r \mathrm{~S}$; mobile elements intI1, Tn916/1545; and the 16S rRNA genes. The primers and annealing temperature were summarized in Supporting information.

\subsection{High-throughput sequencing based on $16 \mathrm{~S}$ rRNA gene}

Three independently sampled DNA extracts were mixed and sequenced for microbial community analysis. PCR primers 515F/806R targeting the bacterial and archaeal 16S V4 genomic region were selected for microbial community analysis. Pairs of reads from the original DNA fragments were merged using FLASH and then filtered using QIIME quality filters. PCR chimeras were filtered out in UCHIME. The screened high-quality reads were clustered by OTUs (Operational Taxonomic Units) at a 97\% similarity level and the abundances and annotations of species were analyzed. The taxonomic classification of the sequences was performed using the Ribosomal Database Project (RDP) Classifier at the bootstrap cutoff of $80 \%$ suggested by the RDP. The sequences were uploaded to MGRAST (https://www.mg-rast.org/index.html) under the project number mgp86710.

\subsection{Statistical analysis}

Tests of data normality were conducted before further statistical analysis. Correlations of the ARGs, MGEs, 16S rRNA, dominant genera were evaluated by Spearman correlation analysis (SPSS 20.0, IBM, USA). Paired $t$-test was performed to evaluate the variations between influents and effluents mean concentrations of ARGs and MGEs by SPSS 20.0, and a $p$-value $<0.05$ was considered statistically significant. Principal 
component analysis (PCA) was used to cluster the distribution of microbial community composition, and the prevalence of ARGs and MGEs of samples using Canoco 5.0 (Microcomputer Power, USA). The heatmap illustrating the evolution of the quantified genes in each sample was conducted by Heml 1.0, and the clusters were based on Pearson distance. Network analysis by Gephi 0.9.2 was used to estimate the co-occurring ARGs, potential host bacteria including potential pathogens based on Spearman correlation analysis (Duan et al., 2017; Zhang et al., 2018b).

Multiple linear regression analyses (Tong et al., 2018) were applied to evaluate the importance of factors on the fate of ARGs (SPSS 20.0). To simplify the bacterial community composition in the multiple linear regression model, a dimension reduction for the dominant genera was first conducted based on a PCA using SPSS 20.0. Subsequently, the top master coordinates (coord1, coord2, coord3, etc.) with a cumulative variance proportion over $80 \%$ were adopted to express the bacterial community. The dimension reduction results of the microbial community are shown in Supporting information. Based on F-tests, the least significant variables were removed from the model via a stepwise variable reduction. A $p$-value $<0.05$ indicates that the multiple linear regression model is statistically significant. The adjusted $R^{2}$ values of the linear regression models indicate the explanatory power of regression models that contain different numbers of predictors.

\section{Results and discussion}

\subsection{Variation in microbial biomass and microbial diversity}

Microbial biomass and microbial diversity are important factors influencing the fates of 
ARGs (Tong et al., 2018), and thus, their variations along different wastewater treatments were investigated (Figure 2). Since sludge could harbor large amounts of organic particles other than microorganisms, and MLVSS in the effluents especially the tertiary effluents were rather low, and thus, the copy number of 16S rRNA rather than MLVSS was employed to represent the microbial biomass. The paired $t$-test results showed the microbial biomass in wastewater significantly decreased after all the secondary treatment process $(p<0.001)$. It is notable that the microbial biomass in the sludge kept decreasing along the anaerobic-anoxic-oxic process of plant $\mathrm{E}$ and $\mathrm{F}$, even carbon source was added in the anoxic tank for denitrification. This might be due to the amount of microbial biomass in each tank was changed by the sludge cycling (from the settling tank to the anaerobic tank and from the oxic tank to the anoxic tank) (Semblante et al., 2014).

The Chao1 index, Pielou index, and Shannon index were investigated (Figure 2). The microbial richness and evenness in the sludge were higher than that of the influent communities due to the abundant microbial in the sludge, which is consistent with the previous study (Lee et al., 2015). Although the microbial biomass in the wastewater reduced after treatment, the Pielou and Shannon index of the effluents increased in all plants except plant F. These results indicated that that biological treatment could enrich the microbial diversity, especially the microbial evenness. As for plant $\mathrm{F}$, the three microbial diversity indexes for the effluent were less than that for the influent. In addition, the three microbial diversity indexes for the sludge of plant $\mathrm{F}$ were lower than that of other plants, whereas the microbial biomass was similar. These results might be due to that the 
industrial wastewater in influent of plant $\mathrm{F}$ were mainly treated coking wastewater and steel industrial wastewater, which might harbor cyanides and thiocyanate and then restrain the microbial diversity (Kim et al., 2011).

\subsection{Evolution of microbial community}

PCA analysis shows that the microbial community structures could be clustered into four groups (Figure 3a): i.e. all influents; effluents of plant A to E together with their corresponding settling tank samples; sludge from plant A to E; the sludge, secondary and tertiary effluents of plant $\mathrm{F}$. The microbial community of anaerobic tank, anoxic tank, aeration tank of $\mathrm{A}^{2} / \mathrm{O}$, CASS or OD processes treating domestic wastewater displayed a similar microbial community structure, indicating that different treatment technologies treating similar influent would lead to similar sludge microbial community in the bioreactors. Likewise, a previous study reported that the sludge from $\mathrm{A}^{2} / \mathrm{O}$ and $\mathrm{A} / \mathrm{O}$ process treating municipal wastewater shared similar microbial community (Zhang et al., 2018a). In plant $F$, the microbial communities of the sludge and effluent samples were different from that of other plants, which could be caused by the different wastewater resources (Lee et al., 2015).

Heatmap (Figure 3b) shows the detail evolution and clusters of the microbial community at the genus level along with wastewater treatment in the six plants. Arcobacter was the most dominant bacteria in the influents of all plants, with an abundance of $17.26 \%-47.31 \%$, followed by Bacteroides (2.56\% - 7.06\%), Acinetobacter (1.82\% - 9.42\%), Macellibacteroides (1.66\% - 4.78\%), Pseudomonas (1.70\% - 4.39\%), 
Aeromonas $(0.45 \%$ - 3.37\%), Trichococcus $(1.45 \%$ - 2.97\%), etc. All these genera except Macellibacteroides have been previously reported as dominant bacteria in the influent of WWTPs (McLellan et al., 2010; VandeWalle et al., 2012). Macellibacteroides has been previously found in a slaughterhouse waste (Jabari et al., 2012) and sewage sludge (Huang et al., 2016). It should be noted that Arcobacter might be pathogenic to humans and animals (Levican et al., 2016) and may lead to the spreading of infectious diseases. Genera Bacteroides, Acinetobacter, Pseudomonas, and Aeromonas were revealed as potential pathogens according to the virulence factor database (VFDB, http://www.mgc.ac.cn/VFs/), and host bacteria of different types of ARGs and multidrug resistance according to the antibiotic resistance gene database (ARDB, http://ardb.cbcb.umd.edu/). The results indicate that the influent of WWTPs harbors large amounts of pathogens and potential host bacteria of ARGs, which needed to be removed to reduce the risk of resistance dissemination.

Secondary wastewater treatment systems of all plants showed effective removal of Arcobacter, with the abundance of $0.99 \%-4.89 \%$ in the secondary effluent and $1.64 \%$ further reduction during the tertiary treatment process. Similarly, the abundance of Bacteroides and Macellibacteroides was reduced by $1.16 \%-6.27 \%$ in all secondary effluents, whereas the abundance of Pseudomonas, Aeromonas, and Acinetobacter in the effluents decreased in most cases. Exceptionally, Acinetobacter and Aeromonas increased by $1.03 \%$ and $0.07 \%$ in the effluent of plant E, and Pseudomonas increased by $3.67 \%$ in the effluent of plant F. In addition, the tertiary treatment process could further reduce the 
above genera abundance by $0.12 \%-7.15 \%$. These results indicate that the secondary wastewater treatment processes could reduce the potential host bacteria and pathogens, and the tertiary treatment processes provided further reduction of these bacteria.

As for the sludge, genera Phaeodactylibacter (with abundance of $1.13 \%-6.28 \%$ ), Dechloromonas (0.71\% - 20.13\%), Arcobacter (1.31\% - 26.34\%), and Haliscomenobacter $(0.57 \%-8.12 \%)$ were the dominant bacteria in the sludge of plant A to E. However, Thauera (6.64\% - 8.90\%), Nitrospira (8.41\% - 8.54\%), Parvularcula (6.69\% - 7.29\%), Dechloromonas $(3.33 \%-5.87 \%)$, and Nitrosomonas $(3.65 \%-3.76 \%)$ were the dominant bacteria in the sludge of plant $\mathrm{F}$. The different microbial communities between plant $\mathrm{F}$ and other plants could be due to the different types of wastewater treated. Phaeodactylibacter was capable of organic matters removal (Chen et al., 2014), whereas Dechloromonas, Thauera were typical denitrifying bacteria in the wastewater treatment process ( $\mathrm{Wu}$ et al., 2013). Thauera spp. was identified to have a new possibility as denitrifier capable of phosphorous uptake under anoxic condition (Yun et al., 2018). In addition, Nitrosomonas and Nitrospira were the predominant ammonia oxidation bacteria (AOB) and nitrite oxidation bacteria (NOB) in all wastewater treatment plants, which was consistent with the previous study that these two genera were the dominant $\mathrm{AOB}$ and $\mathrm{NOB}$ in a wastewater treatment system (Xu et al., 2018). Although Thauera and Nitrosomonas are important bacteria for nutrients removal in WWTPs, they could be host bacteria of bacitracin resistance genes according to ARDB and might cause prevalence of resistance genes during wastewater treatment. 
The dominant microbial in the effluents of plant A to E were Limnohabitans $(1.43 \%$ $10.83 \%)$, Arcobacter (0.99\% - 4.89\%), Zoogloea (0.56\% - 8.70\%), Flavobacterium $(0.77 \%-7.06 \%)$, Thauera $(0.56 \%-6.56 \%)$, etc. Comparatively, Pseudomonas $(12.73 \%$ and 5.58\%), Propionigenium (10.64\% and $13.92 \%)$, Rheinheimera (7.98\% and $6.10 \%)$, Trichococcus (5.93\% and $10.93 \%)$, were the dominant genera in the second and tertiary effluent of plant F. Propionigenium that can be found in freshwater sediments could decompose succinate to propionate by decarboxylation (Schink, 2006). Flavobacterium was reported to be able to degrade pentachlorophenol (Crawford \& Mohn, 1985). Limnohabitans was ammonia oxidizer and one of the most important bacterial groups in freshwater (Zeng et al., 2012). Although these bacteria are important for reducing pollutants during wastewater treatment, some of these bacteria could harbor ARGs. For example, Flavobacterium is the host of tet $\mathrm{H}$ (Zhang et al., 2009). The finding of potential hosts of ARGs and pathogens (e.g., Pseudomonas, Thauera, and Flavobacterium) in the effluent of WWTPs indicated that the effluents still have the potential of spreading disease and antibiotic resistance to human and animals. In addition, the wastewater and sludge in all plants also harbor other potential pathogens, such as Enterobacter, Escherichia,

Enterococcus, Streptococcus, etc. Although these genera were not the dominant bacteria (with abundances less than $0.43 \%$ ), they could be the host bacteria of diverse ARGs and might contribute antibiotic resistance spreading, which needs further investigation.

\subsection{Fate of ARGs along different wastewater treatment processes}

The PCA analysis shows the distribution of ARGs and MGEs in wastewater and sludge 
could be clustered into 4 groups (Figure 4), i.e. (1) influents of all plants, primary settling tank, sludge from CASS of plant B, sand filter of plant A; (2) all effluents except effluent of plant F, and final settling tank; (3) sludge from all bioreactor tanks other than sludge from plant B; (4) secondary and tertiary settling tank and effluents of plant F. The PCA analysis suggests that the prevalence of ARGs and MGEs in all WWTPs were changed from influent through sludge to the final effluents. This result was consistent with a previous study showing that there is a shift from raw influent through the final effluents on the ARG abundance profiles in a WWTP (Karkman et al., 2016). In addition, the distribution of ARGs and MGEs in the sludge of all plants was similar, despite the microbial community of these sludge were quite different (Figure 3a), indicating that the microbial community might not be the most important factor influencing the distribution of ARGs in the sludge. However, the distribution of ARGs and MGEs of secondary and tertiary effluents of plant $\mathrm{F}$ were different from other effluents, which indicated that the biotreatment process receiving different influents dominated by industrial or domestic wastewater could alter the distribution of ARGs and MGEs in the effluents.

Figure 5a and 5b show the absolute abundance of ARGs and MGEs in the wastewater influent and sludge samples. The secondary wastewater treatment systems of all WWTPs showed effective removal of the total ARGs and total MEGs, with $12.44-24.63$ logs $(p<0.001)$ and $3.25-7.22$ logs reduction $(p<0.001)$, respectively. In addition, secondary treatment in all six plants could also significantly remove $0.70-4.08$ logs of each individual ARGs $(p \leqslant 0.002)$ and 1.28 - 3.79 logs for individual MGEs $(p \leqslant 0.001)$. The 
removal efficiency of total ARGs for the secondary effluents were $28.0 \%$ and $45.5 \%$ for plant A and B (CASS process), 39.7\% and 40.6\% for plant C and D (OD process), 34.5\% and $29.7 \%$ for plant $\mathrm{E}$ and $\mathrm{F}\left(\mathrm{A}^{2} / \mathrm{O}\right)$, respectively. These results indicated that secondary treatment could effectively reduce ARGs. However, it is hard to conclude which treating process was the best for ARGs reduction.

Compared plant A with B, which are CASS process with or without the sand filter, 6.99 and $1.83 \operatorname{logs}$ reduction of total ARGs and MGEs were observed after the sand filter. There was $7.60 \mathrm{mg} / \mathrm{L}$ reduction (i.e. $33.8 \%$ reduction) of $\mathrm{NO}_{3}{ }^{-}-\mathrm{N}$ during the wastewater transferred from the sand filter to the outlet channel, despite the concentrations of COD, $\mathrm{NO}_{2}{ }^{-}-\mathrm{N}, \mathrm{NH}_{4}^{-}-\mathrm{N}$, and $\mathrm{PO}_{4}{ }^{3-}-\mathrm{P}$ of these two sampling spots were similar (data shown in Table 1). This result might be explained by the following reasons: (1) some bacteria such as the denitrifying bacteria showed robust activity even after the sand filter, and might conduct further removal of ARGs and MGEs; (2) $\mathrm{NO}_{3}{ }^{-}-\mathrm{N}$ might be a factor influencing ARGs; (3) there was 1.00 logs decrease of $16 \mathrm{~S}$ rRNA during this transport process, which might also contribute the reduction of total ARGs and MGEs.

The concentration of total ARGs in the influents of plant $E$ and plant $F$ were close to each other, with $52.13 v s .50 .81 \log$ copies/mL, respectively. There were 0.42 and $0.15 \log$ copies/g reduction of total ARGs and total MGEs in the oxic tank (MBBR process) of plant E, but 0.74 and 0.75 logs removal in the oxic tank (activated sludge) of plant F. The results suggested that the MBBR capability on ARGs removal might be less than the removal ability of activated sludge. A previous study also reported that MBBR could not 
efficiently remove the ARB and ARGs when treating mariculture wastewater ( $\mathrm{Li}$ et al., 2017). There was 2.08 and $7.91 \operatorname{logs}$ reduction of total ARGs during the disinfection process of chlorination for plant $\mathrm{E}$ and $\mathrm{F}$, which might due to that $\mathrm{ARB}$ cells were effectively "killed" during disinfection (Dodd, 2012).

Moreover, the tertiary treatment of plant E reduced 6.82 and 2.65 logs total ARGs and MGEs, whereas the tertiary treatment of plant F with Densadeg clarifier followed by cloth filter reduced 1.72 and $0.19 \operatorname{logs}$ total ARGs and MGEs. The better ARGs reduction in the tertiary process of plant E could be explained by the fact that the alkaline condition with lime addition provided a circumstance for bacteria inactivation and DNA damage. Karkman et al (Karkman et al., 2016) also reported that tertiary treatment could efficiently reduce ARG contamination from sewage. Therefore, tertiary wastewater treatments are necessary for further application in resistance reduction.

Figure 5c and 5d show the relative abundance of ARGs and MGEs (i.e. ARG or MGE copies/16S rRNA copies) in the wastewater and sludge samples. intI1 was the most prevalent MGE for all wastewater samples. For most of the wastewater samples of all WWTPs, bla was the dominant ARG for the secondary effluent and tertiary effluent. The relative abundance of qnrS increased in all effluents regardless wastewater treatment processes, especially for the tertiary treatment process of plant F. Likewise, the relative abundance of $q n r \mathrm{~A}$ increased in all effluents only except in the effluent of plant A, indicating that the qnr-genes tend to be persistent ARGs in wastewater compared with other ARGs 
investigated in this study. qnrS and $q n r \mathrm{~A}$ are the plasmid-mediated fluoroquinolone resistance genes, and the plasmids carrying qnr-genes usually also encoded ESBLs genes (Jacoby, 2005; Lautenbach et al., 2001). Although there was no significant correlation between $b l a_{\mathrm{TEM}} /$ bla $a_{\mathrm{CTX}-\mathrm{M}}$ and $q n r \mathrm{~A} / q n r \mathrm{~S}$ both in terms of the absolute and relative abundance in the effluents, the increasing abundance of qnr-genes should get more attention, since it might cause the bacteria potentially co-resistant to fluoroquinolones and $\beta$-lactam antibiotics.

The sludge samples shared the similar distribution of ARGs as that in the wastewater samples, i.e. the most prevalent MGEs was the intI1, whereas bla ${ }_{\mathrm{TEM}}$ was the dominant $\mathrm{ARG}$, followed by erm $\mathrm{F}$ and mef $\mathrm{A} / \mathrm{E}$. When compared the variation of relative abundance of sludge from plant $\mathrm{B}, \mathrm{E}$, and $\mathrm{F}$, the relative abundance of most individual ARGs in the sludge reduced during the anaerobic/anoxic process, but increased during the aeration/oxic process despite the reduction of microbial biomass in oxic tank. The results indicated that aeration tank rather than the anaerobic/anoxic tank might be the main place for HGT. In addition, the host bacteria of ARGs might be harder to be removed compared with nonhost bacteria during the wastewater treatment.

All secondary treatment processes effectively reduced the relative abundance of total ARGs by $14.3 \%-139.9 \%$, which agreed with the observation in previous studies (An et al., 2018; Karkman et al., 2016). However, tertiary treatments might not always reduce the relative abundance of total ARGs. For example, with $35.7 \%$ increase but $10.1 \%$ decrease of ARG abundance for tertiary treatment of plant E and F. Our previous study found that 
the sludge pretreatment under microwave at alkaline condition could reduce the microbial biomass and copy number of ARGs, but increase the total relative abundance of ARGs, and thereby promoting the occurrence of the resistance genotypes of enterococci (Tong et al., 2017). Likewise, the total relative abundance increased during the tertiary treatment of plant E, which might be caused by that the alkaline condition reduced the microbial biomass but some bacteria harboring ARGs selectively survived, and/or resistance genotypes of some bacteria were improved.

\subsection{Co-occurrence ARGs, potential pathogens and potential host bacteria}

The co-occurrence ARGs, potential pathogens according to VFDB, and potential host bacteria other than potential pathogens in the dominant bacteria (top 10 genera of each sample) were analyzed by the network analysis based on Spearman correlation analysis (Figure 6). The co-occurrence ARGs, their potential host bacteria, and the potential pathogens in wastewater (Figure 6a) were different from that in sludge (Figure 6b) in all plants. In wastewater, 15 genera potential pathogens, such as Enterobacter, Escherichia/Shigella, Enterococcus, Streptococcus, etc. showed an intimate relationship with ARGs, indicating that these genera might contribute the spreading of ARGs in the wastewater. However, due to the different microbial community in sludge and wastewater (Figure 3a and 3b), the potential host bacteria showing a significant correlation with ARGs in sludge were different from the potential host bacteria in wastewater. Only two genera potential pathogens Mycobacterium and Mesorhizobium were found having a significant correlation with ARGs. The reason that more potential pathogens genera 
showing significant correlations with ARGs in wastewater than that in sludge might be due to that the higher abundances of these potential pathogen genera in wastewater had more chances to contact ARGs and influence the fate of ARGs through horizontal genes transfer. For example, the abundance of Enterobacter, Escherichia/Shigella,

Enterococcus, Streptococcus in the wastewater in all plants was $0.02 \%-0.42 \%, 0-0.37 \%$, $0-0.03 \%$, while it was $0.01 \%-0.11 \%$, but $0-0.15 \%, 0-0.08 \%, 0-0.02 \%, 0-0.03 \%$ for sludge samples.

In addition, Arcobacter, Comamonas, and Propionigenium, etc. were the potential host bacteria of ARGs and MGEs in wastewater, whereas Terrimonas, Comamonas, Acidovorax, etc. for ARGs and MGEs in sludge. Only the genus Comamonas was observed showing significant correlation with ARGs both in wastewater and sludge. These results indicated the proliferation of Comamonas might promote the abundance of ARGs both in wastewater and sludge.

\subsection{Evaluation of factors impact on the fate of ARGs in full-scale WWTPs}

Stepwise multiple linear regression analyses were applied to evaluate the importance of wastewater characteristics ( $\mathrm{pH}, \mathrm{ALK}$, conductivity, $\mathrm{COD}, \mathrm{NH}_{4}{ }^{+}-\mathrm{N}, \mathrm{NO}_{2}{ }^{-}-\mathrm{N}, \mathrm{NO}_{3}{ }^{-}-\mathrm{N}, \mathrm{TN}$, and $\mathrm{PO}_{4}{ }^{3-}-\mathrm{P}$ ), bacterial community composition (in the genus level), bacterial diversity (Chao1, Pielou, and Shannon index), and MGEs (intI1 and Tn916/1545) on the fate of individual ARGs and total ARGs during wastewater treatment. Multiple linear regression models for ARGs in wastewater and in sludge are shown in Table 2 and 3, respectively.

The multiple linear regression models were highly significant for individual ARGs and 
total ARGs with $p$ values less than 0.001 . The models could explain $87.2 \%-99.7 \%$ of the variations in individual ARGs and total ARGs. Results showed that the main factors influencing ARGs in wastewater were different from that in sludge. For example, $96.3 \%$ 98.6\% of variations of bla $a_{\mathrm{TEM}}$, bla $a_{\mathrm{CTX}-\mathrm{M}}, e r m \mathrm{~F}$, and total ARGs in wastewater were affected by the microbial biomass (i.e. $16 \mathrm{~S}$ rRNA), indicating that reducing the microbial biomass in the wastewater could effectively improve the removal of ARGs. A previous study (Wu et al., 2010) also reported the biomass is an important factor on the fate of ARGs. Therefore, better control of settling or filtration process of secondary treatment, or tertiary treatment should be implemented in full-scale WWTPs to control the spreading of ARGs.

However, the fate of most ARGs in sludge was mainly driven by MGEs, with 72.2\% $92.8 \%$ variations that could be explained by changes of MGEs. In addition, qnrA and qnrS in wastewater were mainly influenced by MGEs, but microbial biomass was the major factor in variations of $q n r \mathrm{~A}$ and $q n r \mathrm{~S}$ in sludge. However, erm $\mathrm{B}$ and $m e f \mathrm{~A} / \mathrm{E}$ both in wastewater and sludge were mainly driven by MGEs. MGEs are considered responsible for HGT of resistance genes (Hegstad et al., 2010). The models showed that the MGEs were the major drivers for ARGs in sludge in most cases, which indicated that the HGT might mainly occur in the biotreatment tanks. This observation is consistent with a previous study showing that a more frequent HGT occurred in the biological units (Su et al., 2014). Therefore, the distribution of ARGs in sludge might be mainly influenced by the MGEs rather than microbial community, which result is consistent with our previous 
study showing that MGEs are the main driver for the fate of ARGs in the sludge during anaerobic digestion sludge treatment (Tong et al., 2018). This result may explain the distribution of ARGs in the sludge of plant F and other plants was similar (Figure 4), despite the microbial community of these sludge were very different (Figure 3a).

Furthermore, the models indicate that microbial diversity, microbial community composition, wastewater characteristics such as conductivity, nutrients $\left(\mathrm{NO}_{2}^{-}-\mathrm{N}, \mathrm{NO}_{3}^{-}{ }^{-} \mathrm{N}\right.$, $\mathrm{TN}$, and $\left.\mathrm{PO}_{4}{ }^{3-}-\mathrm{P}\right), \mathrm{COD}$, and $\mathrm{pH}$, etc. were the factors that significantly affected the fate of ARGs. The models confirmed our previous assumption that $\mathrm{NO}_{3}{ }^{-} \mathrm{N}$ might be a factor influencing the fate of ARGs. The nutrients had a positive effect on the abundance of ARGs in these models, indicating that enhanced nutrients removal process could result in better ARGs removal. In addition, it is believed that numerous factors contribute to the variations of ARGs in a complex interplay (Manaia et al., 2018). For example, the wastewater characteristics could change the microbial community of the sludge in the bioreactors. Moreover, the ARGs and MGEs were harbored by the microbial result in they would be influenced by the distribution of their host bacteria. The multiple linear regression models confirmed that the combination of various influencing factors might result in the increase or reduction of ARGs in wastewater or sludge. Further study on the influencing mechanism on the fate of ARGs and measurements to control ARGs spreading is needed.

\section{Conclusion}

The evolution of microbial community and fate of ARGs along different full-scale 
treatment processes were studied. Similar influents would lead to similar sludge microbial community in the biotreatment tanks, regardless the treatment processes. The prevalence of co-occurrence of potential pathogens and ARGs in wastewater was higher than that in sludge. The main driver for the fate of ARGs in wastewater and sludge was microbial biomass and MGEs, respectively. The combination of wastewater characteristics, microbial diversity, microbial biomass, and MGEs contribute to the variation of ARGs. Finally, further improvement of nutrients removal and tertiary treatment would benefit ARGs removal.

\section{Acknowledgments}

This work was supported by the National Major Science \& Technology Projects for Water Pollution Control and Management of China (2015ZX07203-005), the National Natural Science Foundation of China (No. 51578535), and a China Scholarship Council (CSC) scholarship.

\section{Appendix A. Supplementary data}

Supplementary data related to this article can be found in the online version.

\section{References}

1. An, X.-L., Su, J.-Q., Li, B., Ouyang, W.-Y., Zhao, Y., Chen, Q.-L., Cui, L., Chen, H., Gillings, M.R., Zhang, T. 2018. Tracking antibiotic resistome during wastewater treatment using high throughput quantitative PCR. Environ Int, 117, 146-153.

2. Bengtsson-Palme, J., Hammarén, R., Pal, C., Östman, M., Björlenius, B., Flach, C.-F., Fick, J., Kristiansson, E., Tysklind, M., Larsson, D.J. 2016. Elucidating selection 
processes for antibiotic resistance in sewage treatment plants using metagenomics. Sci Total Environ, 572, 697-712.

3. Chen, Q., An, X., Li, H., Su, J., Ma, Y., Zhu, Y.G. 2016. Long-term field application of sewage sludge increases the abundance of antibiotic resistance genes in soil. Environ Int, 92-93, 1-10.

4. Chen, Z., Lei, X., Lai, Q., Li, Y., Zhang, B., Zhang, J., Zhang, H., Yang, L., Zheng, W., Tian, Y. 2014. Phaeodactylibacter xiamenensis gen. nov., sp. nov., a member of the family Saprospiraceae isolated from the marine alga Phaeodactylum tricornutum. Int J Syst Evol Microbiol, 64(10), 3496-3502.

5. Crawford, R., Mohn, W. 1985. Microbiological removal of pentachlorophenol from soil using a Flavobacterium. Enzyme Microb Technol, 7(12), 617-620.

6. Dodd, M.C. 2012. Potential impacts of disinfection processes on elimination and deactivation of antibiotic resistance genes during water and wastewater treatment. Journal of enyironmental monitoring : JEM, 14(7), 1754-1771.

7. Duan, M., Li, H., Gu, J., Tuo, X., Sun, W., Qian, X., Wang, X. 2017. Effects of biochar on reducing the abundance of oxytetracycline, antibiotic resistance genes, and human pathogenic bacteria in soil and lettuce. Environ Pollut, 224, 787-795.

8. Fan, X.-Y., Gao, J.-F., Pan, K.-L., Li, D.-C., Dai, H.-H. 2017. Temporal dynamics of bacterial communities and predicted nitrogen metabolism genes in a full-scale wastewater treatment plant. RSC Advances, 7(89), 56317-56327.

9. Fan, X.Y., Gao, J.F., Pan, K.L., Li, D.C., Dai, H.H., Li, X. 2018. Functional genera, 
potential pathogens and predicted antibiotic resistance genes in 16 full-scale wastewater treatment plants treating different types of wastewater. Bioresour Technol, 268, 97-106.

10. Guo, J., Li, J., Chen, H., Bond, P.L., Yuan, Z. 2017. Metagenomic analysis reveals wastewater treatment plants as hotspots of antibiotic resistance genes and mobile genetic elements. Water Res, 123, 468-478.

11. Guo, M.T., Yuan, Q.B., Yang, J. 2015. Distinguishing effects of ultraviolet exposure and chlorination on the horizontal transfer of antibiotic resistance genes in municipal wastewater. Environmental science \& technology, 49(9), 5771-5778.

12. Hegstad, K., Mikalsen, T., Coque, T.M., Werner, G., Sundsfjord, A. 2010. Mobile genetic elements and their contribution to the emergence of antimicrobial resistant Enterococcus faecalis and Enterococcus faecium. Clin Microbiol Infect, 16(6), 541554.

13. Huang, H.N., Zheng, X., Chen, Y.G., Liu, H., Wan, R., Su, Y.L. 2017. Alkaline fermentation of waste sludge causes a significant reduction of antibiotic resistance genes in anaerobic reactors. Sci Total Environ, 580, 380-387.

14. Huang, X., Mu, T., Shen, C., Lu, L., Liu, J. 2016. Effects of bio-surfactants combined with alkaline conditions on volatile fatty acid production and microbial community in the anaerobic fermentation of waste activated sludge. Int Biodeterior Biodegrad, 114, 24-30.

15. Jabari, L., Gannoun, H., Cayol, J.-L., Hedi, A., Sakamoto, M., Falsen, E., Ohkuma, 
M., Hamdi, M., Fauque, G., Ollivier, B. 2012. Macellibacteroides fermentans gen. nov., sp. nov., a member of the family Porphyromonadaceae isolated from an upflow anaerobic filter treating abattoir wastewaters. Int J Syst Evol Microbiol, 62(10), 25222527.

16. Jacoby, G.A. 2005. Mechanisms of resistance to quinolones. Clin Infect Dis, 41 Suppl 2, S120-126.

17. Ju, F., Li, B., Ma, L., Wang, Y., Huang, D., Zhang, T. 2016. Antibiotic resistance genes and human bacterial pathogens: Co-occurrence, removal, and enrichment in municipal sewage sludge digesters. Water Res, 91, 1-10.

18. Karkman, A., Johnson, T.A., Lyra, C., Stedtfeld, R.D., Tamminen, M., Tiedje, J.M., Virta, M. 2016. High-throughput quantification of antibiotic resistance genes from an urban wastewater treatment plant. FEMS Microbiol Ecol, 92(3).

19. Kim, Y.M., Lee, D.S., Park, C., Park, D., Park, J.M. 2011. Effects of free cyanide on microbial communities and biological carbon and nitrogen removal performance in the industrial activated sludge process. Water Res, 45(3), 1267-1279.

20. Koczura, R., Mokracka, J., Taraszewska, A., Łopacinska, N. 2016. Abundance of class 1 integron-integrase and sulfonamide resistance genes in river water and sediment is affected by anthropogenic pressure and environmental factors. Microb Ecol, 72(4), 909-916.

21. Lautenbach, E., Strom, B.L., Bilker, W.B., Patel, J.B., Edelstein, P.H., Fishman, N.O. 2001. Epidemiological investigation of fluoroquinolone resistance in infections due to 
extended-spectrum $\beta$-lactamase-producing Escherichia coli and Klebsiella pneumoniae. Clin Infect Dis, 33(8), 1288-1294.

22. Lee, S.H., Kang, H.J., Park, H.D. 2015. Influence of influent wastewater communities on temporal variation of activated sludge communities. Water Res, 73, 132-144.

23. Levican, A., Collado, L., Figueras, M.J. 2016. The use of two culturing methods in parallel reveals a high prevalence and diversity of Arcobacter spp. in a wastewater treatment plant. BioMed research international, 2016.

24. Li, S., Zhang, S., Ye, C., Lin, W., Zhang, M., Chen, L., Li, J., Yu, X. 2017. Biofilm processes in treating mariculture wastewater may be a reservoir of antibiotic resistance genes. Marine pollution bulletin, 118(1-2), 289-296.

25. Makowska, N., Koczura, R., Mokracka, J. 2016. Class 1 integrase, sulfonamide and tetracycline resistance genes in wastewater treatment plant and surface water. Chemosphere, 144, 1665-1673.

26. Manaia, C.M., Rocha, J., Scaccia, N., Marano, R., Radu, E., Biancullo, F., Cerqueira, F., Fortunato, G., Iakovides, I.C., Zammit, I., Kampouris, I., Vaz-Moreira, I., Nunes, O.C. 2018. Antibiotic resistance in wastewater treatment plants: Tackling the black box. Environ Int, 115, 312-324.

27. McLellan, S., Huse, S., Mueller - Spitz, S., Andreishcheva, E., Sogin, M. 2010. Diversity and population structure of sewage - derived microorganisms in wastewater treatment plant influent. Environ Microbiol, 12(2), 378-392.

28. Pruden, A. 2014. Balancing water sustainability and public health goals in the face of 
growing concerns about antibiotic resistance. Environ Sci Technol, 48(1), 5-14.

29. Rafraf, I.D., Lekunberri, I., Sanchez-Melsio, A., Aouni, M., Borrego, C.M., Balcazar, J.L. 2016. Abundance of antibiotic resistance genes in five municipal wastewater treatment plants in the Monastir Governorate, Tunisia. Environ Pollut, 219, 353-358.

30. Schink, B. 2006. The genus Propionigenium. in: The Prokaryotes, Springer, pp. $955-$ 959.

31. Semblante, G.U., Hai, F.I., Ngo, H.H., Guo, W., You, S.-J., Price, W.E., Nghiem, L.D. 2014. Sludge cycling between aerobic, anoxic and anaerobic regimes to reduce sludge production during wastewater treatment: Performance, mechanisms, and implications. Bioresour Technol, 155, 395-409.

32. Su, H.C., Ying, G.G., He, L.Y., Liu, Y.S., Zhang, R.Q., Tao, R. 2014. Antibiotic resistance, plasmid-mediated quinolone resistance (PMQR) genes and ampC gene in two typical municipal wastewater treatment plants. Environ Sci Process Impacts, $16(2), 324-332$.

33. Sun, Y., Shen, Y.-X., Liang, P., Zhou, J., Yang, Y., Huang, X. 2016. Multiple antibiotic resistance genes distribution in ten large-scale membrane bioreactors for municipal wastewater treatment. Bioresour Technol, 222, 100-106.

34. Tong, J., Lu, X.T., Zhang, J.Y., Angelidaki, I., Wei, Y.S. 2018. Factors influencing the fate of antibiotic resistance genes during thermochemical pretreatment and anaerobic digestion of pharmaceutical waste sludge. Environ Pollut, https://doi.org/10.1016/j.envpol.2018.09.096 
35. Tong, J., Lu, X.T., Zhang, J.Y., Sui, Q.W., Wang, R., Chen, M.X., Wei, Y.S. 2017. Occurrence of antibiotic resistance genes and mobile genetic elements in enterococci and genomic DNA during anaerobic digestion of pharmaceutical waste sludge with different pretreatments. Bioresour Technol, 235, 316-324.

36. VandeWalle, J., Goetz, G., Huse, S., Morrison, H., Sogin, M., Hoffmann, R., Yan, K., McLellan, S. 2012. Acinetobacter, Aeromonas and Trichococcus populations dominate the microbial community within urban sewer infrastructure. Environ Microbiol, 14(9), 2538-2552.

37. Wei, Z., Feng, K., Li, S., Zhang, Y., Chen, H., Yin, H., Xu, M., Deng, Y. 2018. Exploring abundance, diversity and variation of a widespread antibiotic resistance gene in wastewater treatment plants. Environ Int, 117, 186-195.

38. Wu, N., Qiao, M., Zhang, B., Cheng, W.-D., Zhu, Y.-G. 2010. Abundance and diversity of tetracycline resistance genes in soils adjacent to representative swine feedlots in China. Environ Sci Technol, 44(18), 6933-6939.

39. Wu, W., Yang, L., Wang, J. 2013. Denitrification performance and microbial diversity in a packed-bed bioreactor using PCL as carbon source and biofilm carrier. Appl Microbiol Biotechnol, 97(6), 2725-2733.

40. Xu, J., He, J., Wang, M., Li, L. 2018. Cultivation and stable operation of aerobic granular sludge at low temperature by sieving out the batt-like sludge. Chemosphere, 211, 1219-1227.

41. Yang, Y., Li, B., Zou, S., Fang, H.H., Zhang, T. 2014. Fate of antibiotic resistance 
genes in sewage treatment plant revealed by metagenomic approach. Water Res, 62, 97-106.

42. Yuan, Q.B., Guo, M.T., Yang, J. 2015. The sludge loading rate regulates the growth and release of heterotrophic bacteria resistant to six types of antibiotics in wastewater activated sludge. Environ Sci Process Impacts, 17(1), 206-212.

43. Yun, G., Lee, H., Hong, Y., Kim, S., Daigger, G.T., Yun, Z. 2018. The difference of morphological characteristics and population structure in PAO and DPAO granular sludges. J Environ Sci-China, https://doi.org/10.1016/j.jes.2018.06.003

44. Zeng, Y., Kasalický, V., Šimek, K., Koblížek, M. 2012. Genome Sequences of Two Freshwater Betaproteobacterial Isolates, Limnohabitans Species Strains Rim28 and Rim47, Indicate Their Capabilities as Both Photoautotrophs and Ammonia Oxidizers. J Bacteriol, 194(22), 6302-6303.

45. Zhang, B., Xia, Y., Wen, X., Wang, X., Yang, Y., Zhou, J., Zhang, Y. 2016. The composition and spatial patterns of bacterial virulence factors and antibiotic resistance genes in 19 wastewater treatment plants. PLOS ONE, 11(12), e0167422.

46. Zhang, B., Yu, Q., Yan, G., Zhu, H., yang Xu, X., Zhu, L. 2018a. Seasonal bacterial community succession in four typical wastewater treatment plants: correlations between core microbes and process performance. Sci Rep-Uk, 8(1), 4566.

47. Zhang, J., Sui, Q., Tong, J., Zhong, H., Wang, Y., Chen, M., Wei, Y. 2018b. Soil types influence the fate of antibiotic-resistant bacteria and antibiotic resistance genes following the land application of sludge composts. Environ Int, 118, 34-43. 
48. Zhang, X.X., Zhang, T., Fang, H.H. 2009. Antibiotic resistance genes in water environment. Appl Microbiol Biotechnol, 82(3), 397-414.

49. Zheng, J., Gao, R.X., Wei, Y.Y., Chen, T., Fan, J.Q., Zhou, Z.C., Makimilua, T.B., Jiao, Y.N., Chen, H. 2017. High-throughput profiling and analysis of antibiotic resistance genes in East Tiaoxi River, China. Environ Pollut, 230, 648-654. 
$\underline{\text { Plant A }}$

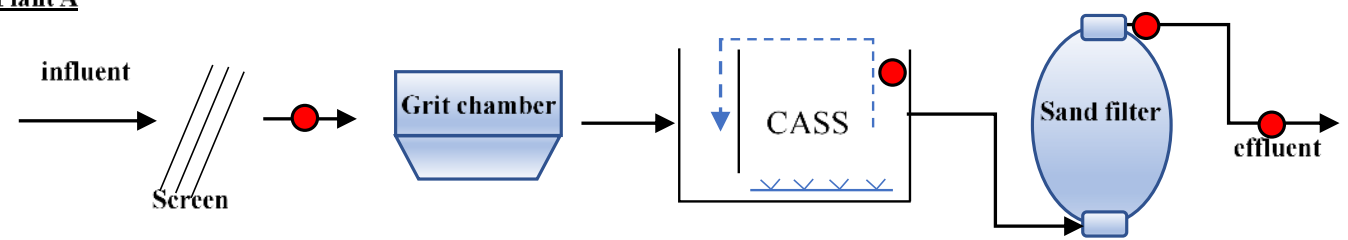

$\underline{\text { Plant B }}$

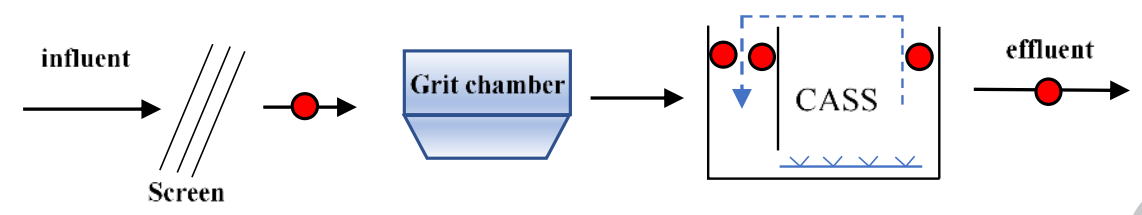

Plant C\&D

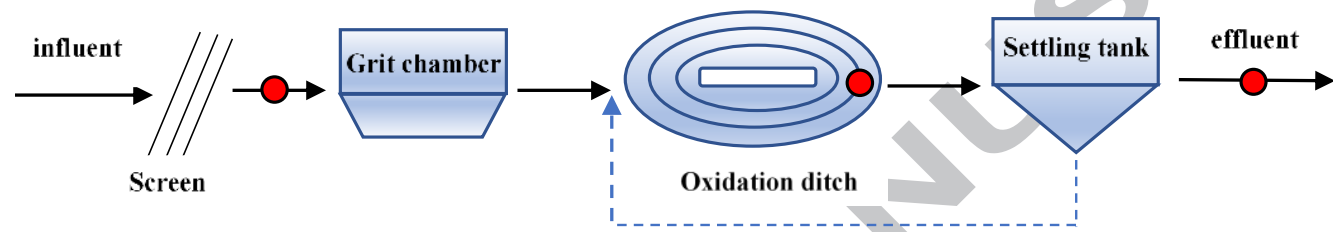

$\underline{\text { Plant E }}$
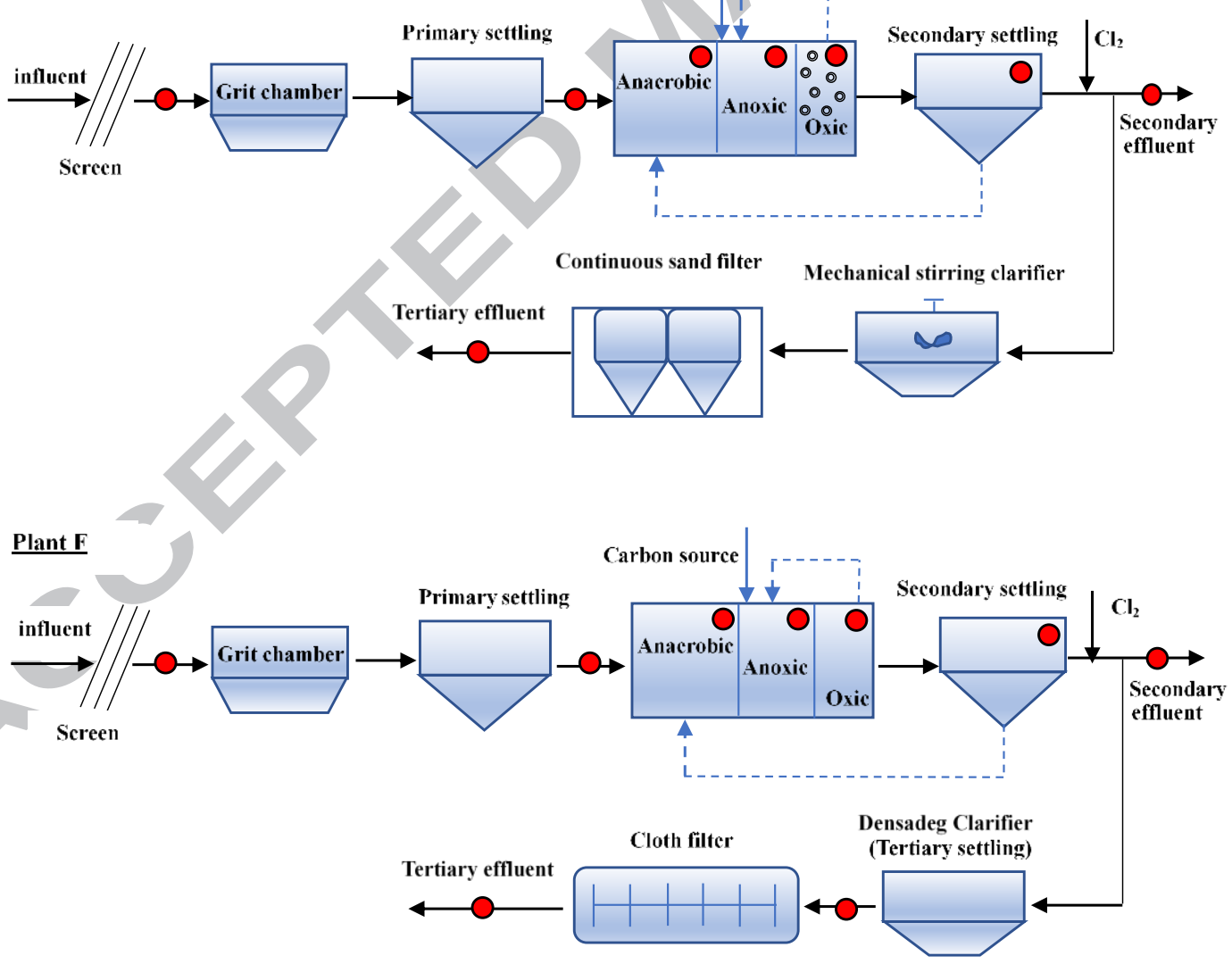

Figure 1 Flow chart of the treatment processes of the six WWTPs and the sampling sites location (shown in red dots). The dashed line represents the recycled sludge. 


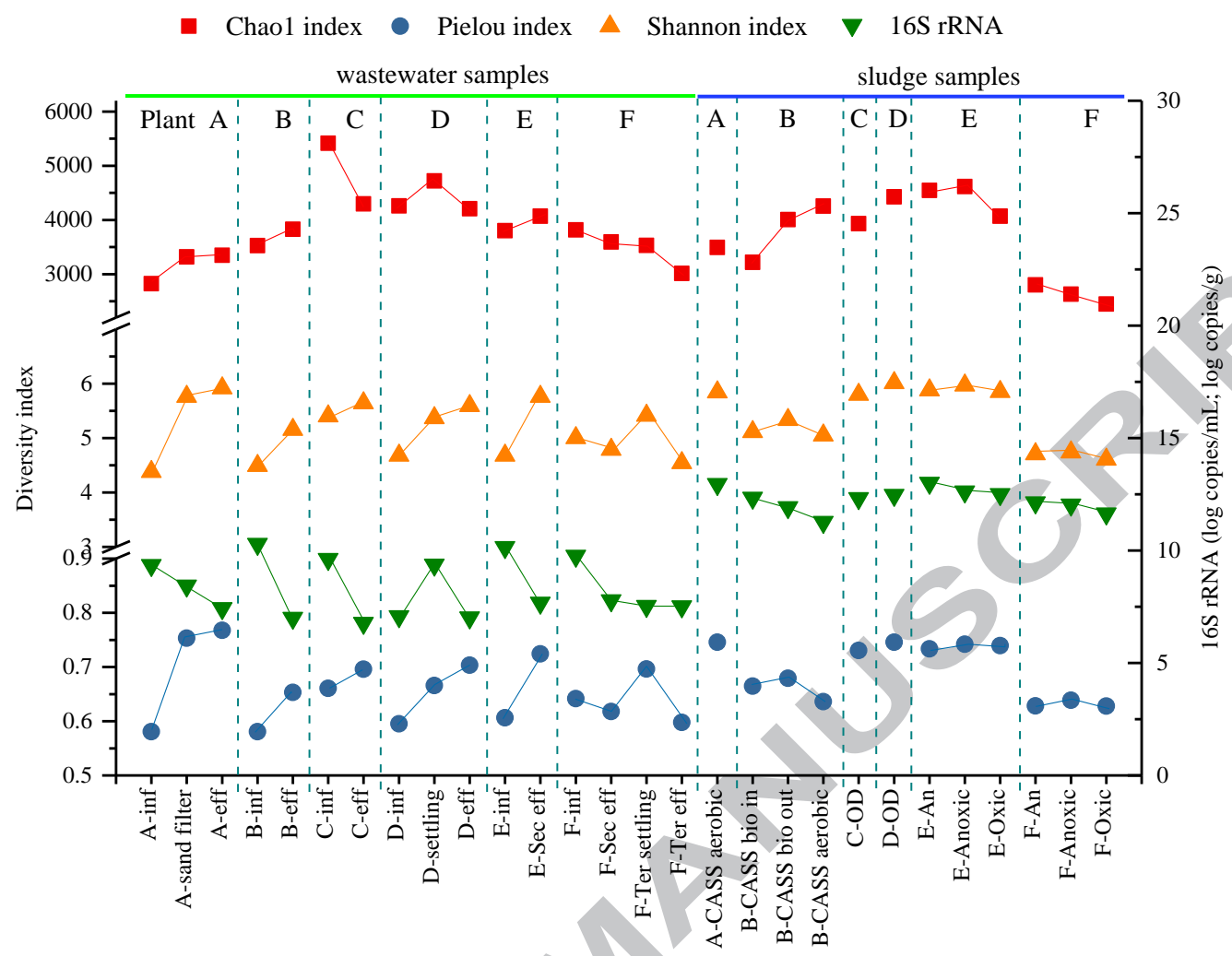

Figure 2 Microbial diversity in wastewater and sludge. Abbreviations of samples are as follows: A-inf, B-inf, C-inf, D-inf, E-inf, F-inf: influent of plant A to F; A-eff, B-eff, C-eff, D-eff, E-sec eff, F-Sec eff, F-Ter eff: secondary and tertiary effluent of plant A to F; Asand filter, outlet sample of sand filter of plant A; C-settling, D-settling, F-Sec settling, FTer settling: wastewater samples of the outlet of secondary and tertiary settling tank of plant C, D, F; B-CASS bio in, B-CASS bio out: sludge of inlet and outlet of bioselection tank of plant B; A-CASS aerobic, B-CASS aerobic: sludge of aeration zone of CASS; COD, D-OD: sludge of OD tank of plant C and D; E-An, E-Anoxic, E-Oxic, F-An, FAnoxic, F-Oxic: sludge of anaerobic, anoxic, and oxic tank of plant E and F. 


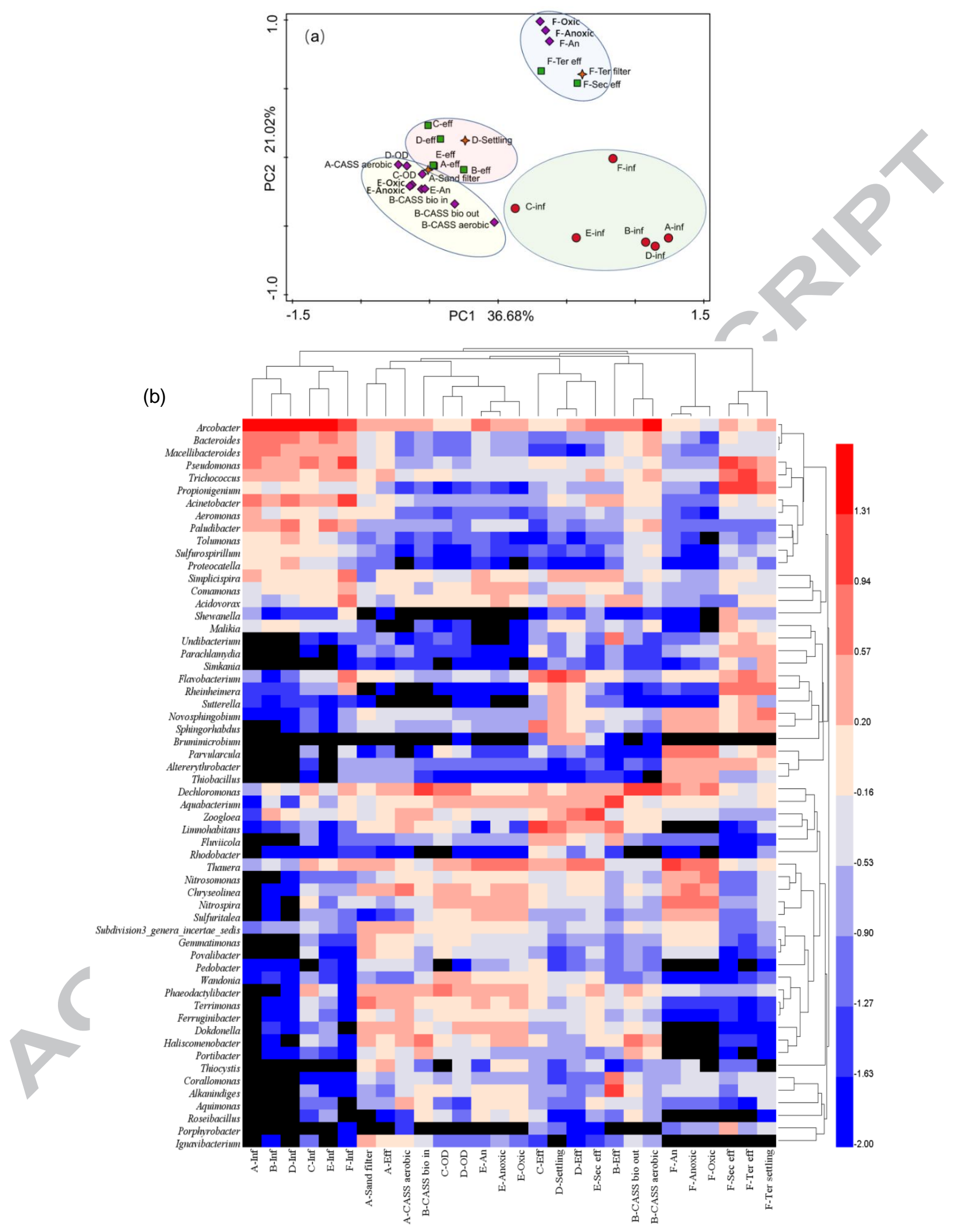

Figure 3 Microbial community evolution during wastewater treatment. (a) PCA analysis based on the genus

abundance. (b) Heatmap of the top 10 genera in each sample based on the genus abundance (log 10 
transformed). Abbreviations of sample names are as defined as Figure 2. 


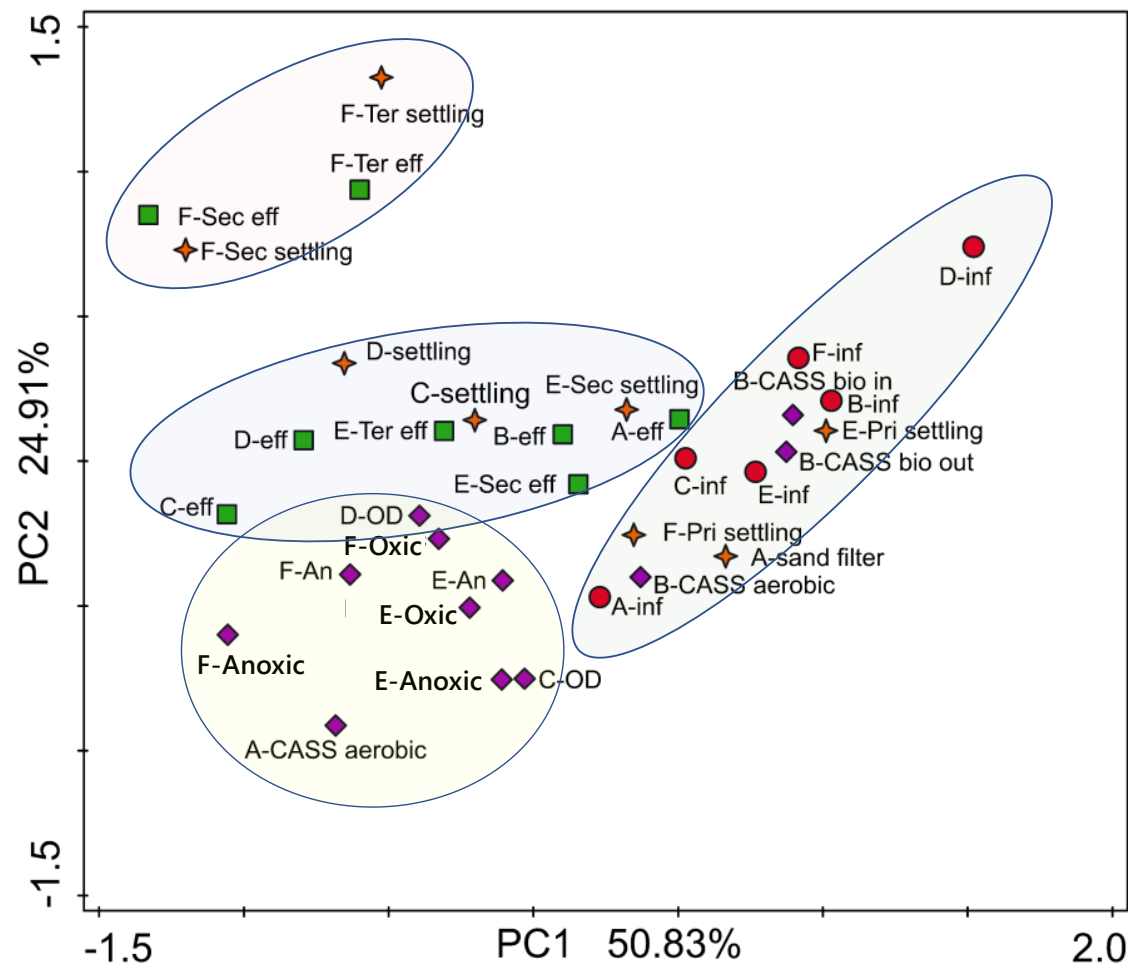

Figure 4 PCA analysis for cluster the distribution ARGs in WWTPs based on the relative abundance of ARGs and MGEs. Abbreviations of sample names: E-pri settling, F-pri settling: wastewater samples of the outlet of primary settling tank of plant $\mathrm{E}$ to $\mathrm{F}$; other abbreviations of sample names are as defined in Figure 2. 
(a)
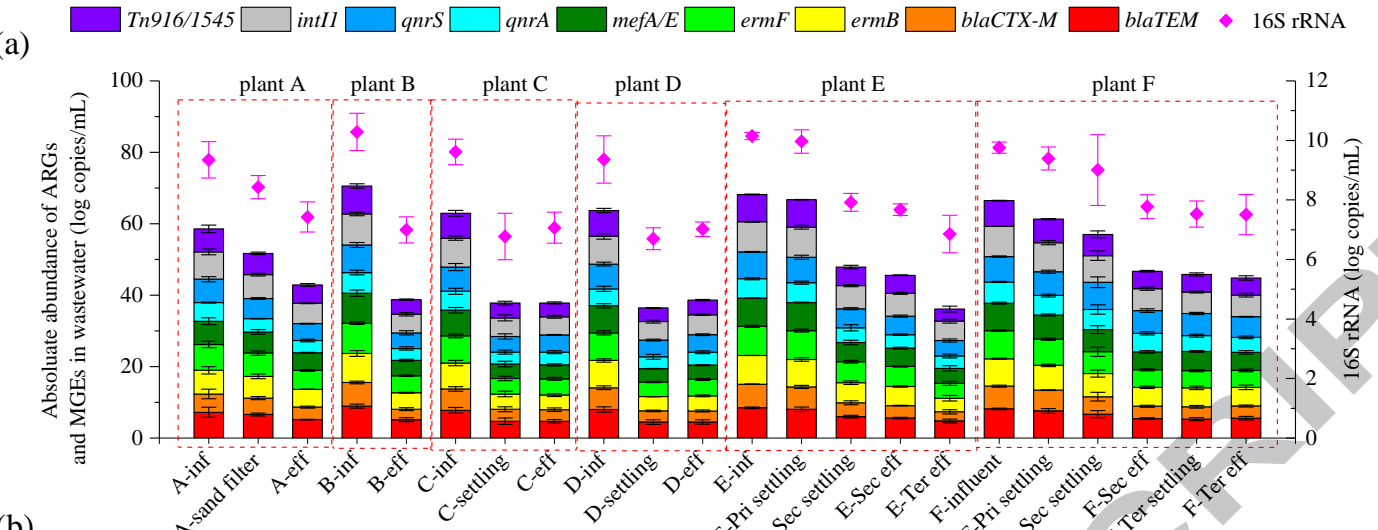

(b)

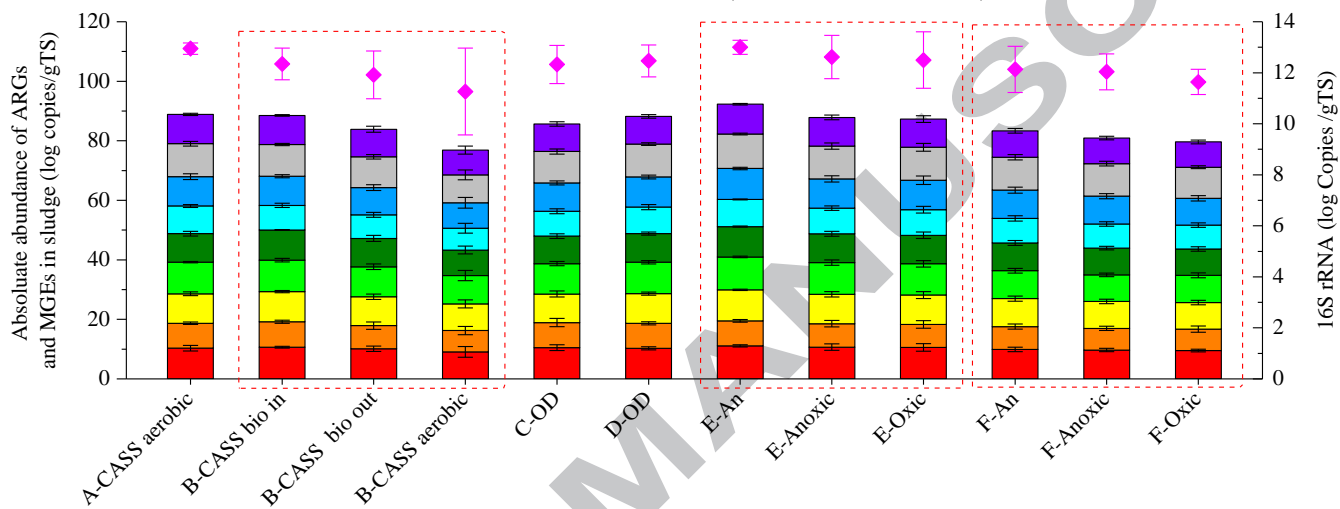

$\square$ Tn916/1545 $\square$ intII $\square$ qnis $\square$ qnrA $\square$ mefA/E $\square$ ermF $\square$ ermB $\square$ blaCTX-M $\square$ blaTEM

(c)

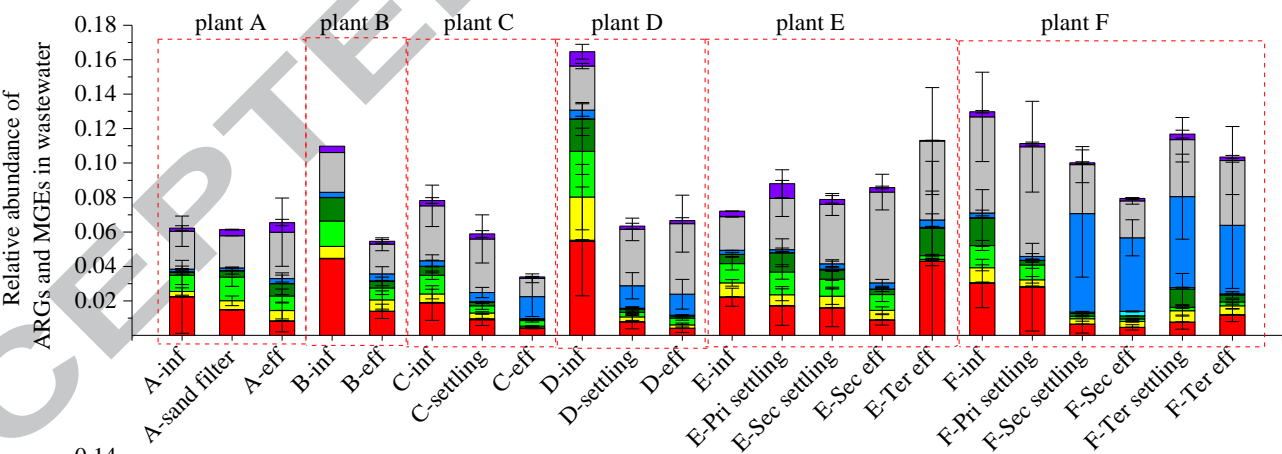

(a)

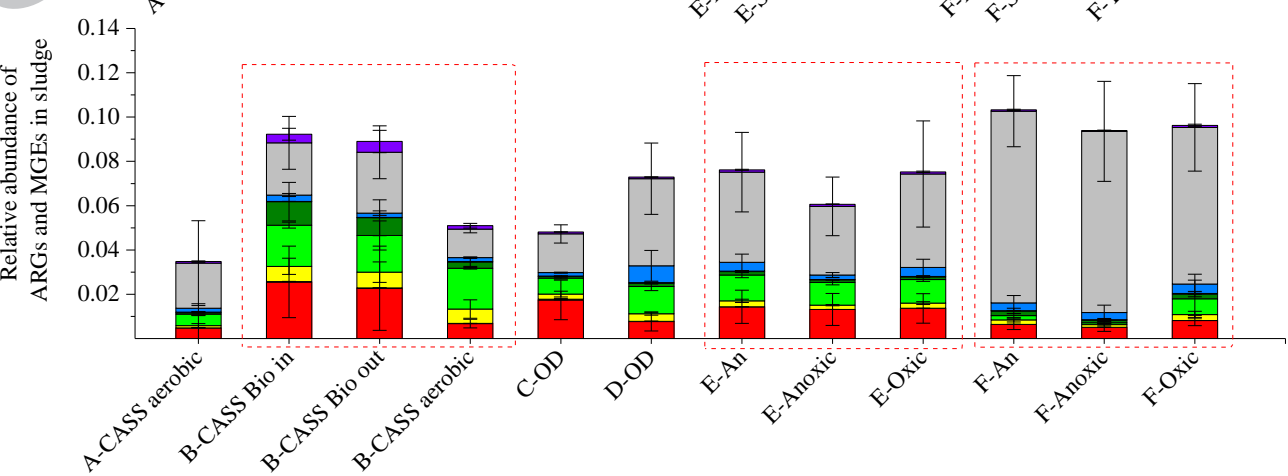

Figure 5 Variations of the abundance of ARGs and MGEs along wastewater treatment systems. Abbreviations of sample names are as defined in Figure 2. 


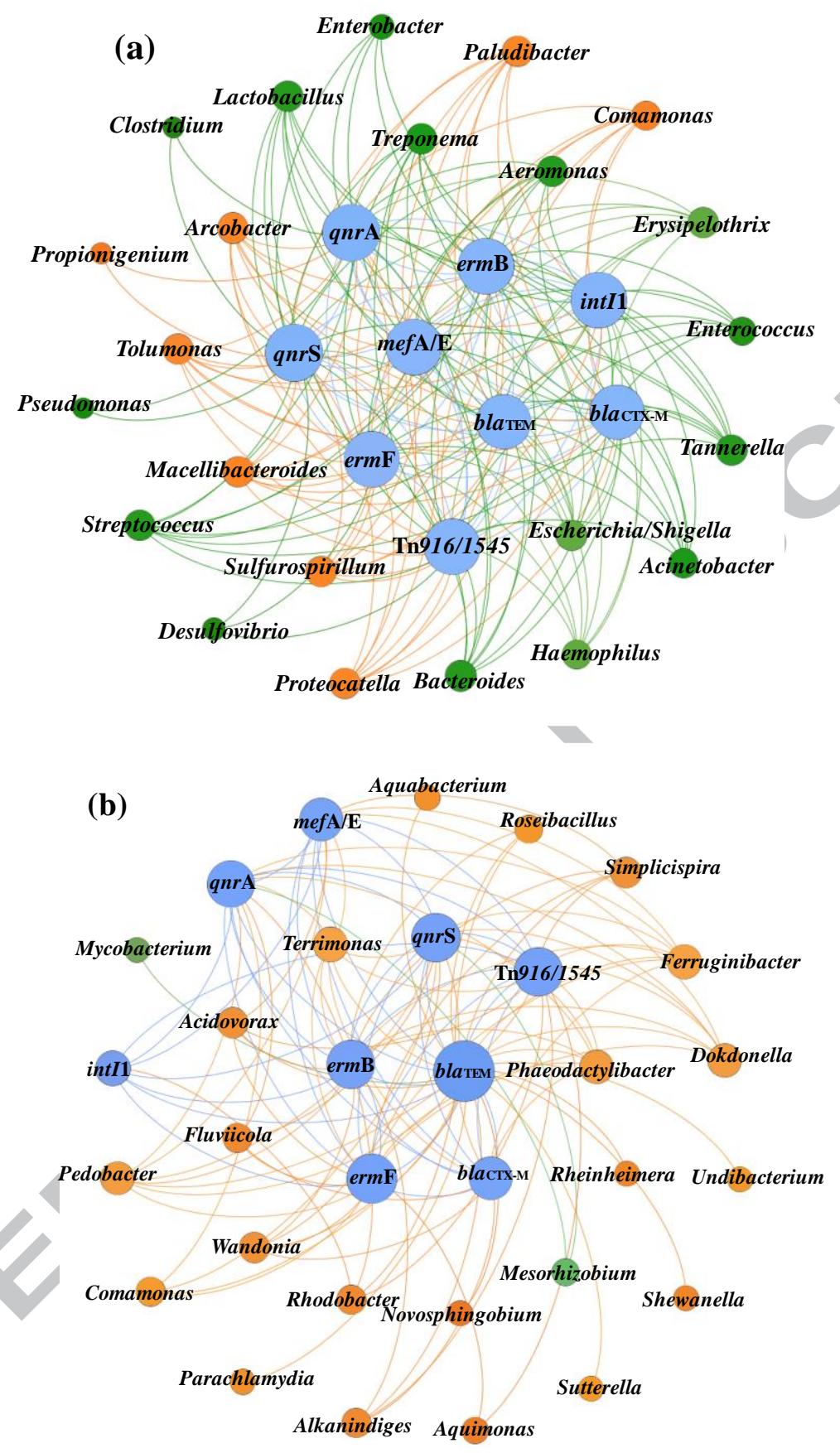

Figure 6 Network analysis showing the co-occurrence of ARGs, MGEs and potential host bacteria in (a) wastewater and (b) sludge according to Spearman correlation analysis. The potential pathogens were identified in VFDB. The size of the circle indicates the amounts of the potential host bacteria. Blue nodes: ARGs and MGEs; orange nodes: potential host 
bacteria but not potential pathogens in dominant bacteria (top 10 genera of each sample); green nodes: potential pathogens. 
Table 1 Wastewater characteristics along the wastewater treatment process

\begin{tabular}{|c|c|c|c|c|c|c|c|c|c|}
\hline Samples & $\mathrm{pH}$ & $\begin{array}{l}\text { Conductivity } \\
, \mu \mathrm{s} / \mathrm{cm}\end{array}$ & $\begin{array}{l}\mathrm{COD}, \\
\mathrm{mg} / \mathrm{L}\end{array}$ & $\begin{array}{l}\mathrm{ALK}, \mathrm{mg} \\
\mathrm{CaCO}_{3} / \mathrm{L}\end{array}$ & $\begin{array}{l}\mathrm{NH}_{4}{ }^{+}-\mathrm{N} \\
\mathrm{mg} / \mathrm{L}\end{array}$ & $\begin{array}{l}\mathrm{NO}_{2}^{-}-\mathrm{N}, \\
\mathrm{mg} / \mathrm{L}\end{array}$ & $\begin{array}{l}\mathrm{NO}_{3}{ }^{-}-\mathrm{N} \\
\mathrm{mg} / \mathrm{L}\end{array}$ & $\begin{array}{l}\mathrm{TN}, \\
\mathrm{mg} / \mathrm{L}\end{array}$ & $\begin{array}{l}\mathrm{PO}_{4}{ }^{3-}- \\
\mathrm{P}, \mathrm{mg} / \mathrm{L}\end{array}$ \\
\hline \multirow{2}{*}{ A-influent } & 8.23 & 133 & 255 & $432.0 \pm 4$ & 59.93 & 0.05 & $0.02 \pm$ & $59.99 \pm$ & 3.94 \\
\hline & \pm 1.08 & 4 & \pm 26 & 1.16 & \pm 6.29 & \pm 0.02 & 0.02 & 6.25 & \pm 0.93 \\
\hline A-CASS & 7.01 & & 126 & $327.6 \pm 5$ & $9.10 \pm$ & 0.02 & 16.31 & $25.43 \pm$ & 5.29 \\
\hline out & \pm 0.66 & $933 \pm 42$ & \pm 46 & 9.37 & 2.46 & \pm 0.03 & \pm 6.41 & 7.71 & 1.32 \\
\hline A-sand & 7.59 & $758 \pm 16$ & $24 \pm$ & $170.6 \pm 3$ & $2.70 \pm$ & 1.12 & 22.51 & & $2.3 \pm$ \\
\hline filter & \pm 0.87 & 1 & 9 & 5.58 & 2.61 & \pm 1.10 & \pm 2.76 & 0.95 & 0.18 \\
\hline \multirow{2}{*}{ A-effluent } & $7.3 \pm$ & & $26 \pm$ & $169.6 \pm 2$ & $2.88 \pm$ & 1.00 & 14.91 & $18.79 \pm$ & 2.09 \\
\hline & 0.51 & $919 \pm 14$ & 9 & 5.03 & 3.51 & \pm 1.26 & \pm 7.47 & 9.84 & \pm 0.85 \\
\hline \multirow{2}{*}{ B-influent } & $7.8 \pm$ & $1731 \pm 3$ & 353 & $468.0 \pm 4$ & 70.63 & 0.03 & $2.18 \pm$ & $72.84 \pm$ & 5.32 \\
\hline & 0.43 & 79 & \pm 150 & 6.31 & \pm 9.02 & \pm 0.03 & 1.00 & 9.72 & \pm 1.23 \\
\hline B-CASS & 7.54 & $1599 \pm 3$ & 278 & $443.4 \pm 1$ & 67.14 & 0.01 & $1.69 \pm$ & $68.84 \pm$ & 18.9 \\
\hline bio in & \pm 0.37 & 45 & \pm 132 & 25.8 & \pm 8.44 & \pm 0.01 & 1.51 & 7.14 & $8 \pm 9.97$ \\
\hline B-CASS & 7.54 & $1514 \pm 1$ & 307 & $432.3 \pm 1$ & 52.85 & 0.08 & $0.43 \pm$ & $53.37 \pm$ & 19.4 \\
\hline bio out & \pm 0.45 & 94 & \pm 95 & 09.5 & \pm 19.69 & \pm 0.11 & 0.35 & 19.89 & $3 \pm 3.91$ \\
\hline B-CASS & 7.19 & $1293 \pm 2$ & $77 \pm$ & $311.1 \pm 2$ & $5.70 \pm$ & 0.08 & 14.48 & $20.25 \pm$ & 5.91 \\
\hline out & \pm 0.48 & 24 & 79 & 0.37 & 3.02 & \pm 0.09 & \pm 2.84 & 0.45 & \pm 1.87 \\
\hline \multirow{2}{*}{ B-effluent } & 7.51 & $1180 \pm 2$ & $25 \pm$ & $257.7 \pm 8$ & $1.55 \pm$ & 0.14 & 16.62 & $18.31 \pm$ & 2.49 \\
\hline & \pm 0.62 & 20 & 13 & 6.32 & 1.87 & \pm 0.11 & \pm 2.75 & 0.82 & \pm 0.58 \\
\hline \multirow{2}{*}{ C-influent } & 7.97 & $2300 \pm 2$ & & $703.2 \pm 1$ & 45.25 & 0.01 & $0.38 \pm$ & $45.64 \pm$ & 3.60 \\
\hline & \pm 0.24 & 40 & & 34.1 & \pm 7.3 & \pm 0.01 & 0.05 & 7.31 & \pm 2.98 \\
\hline \multirow{2}{*}{ C-OD out } & 7.24 & 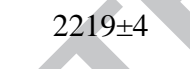 & $44 \pm$ & $414.0 \pm 4$ & $6.83 \pm$ & 0.04 & 14.48 & $21.35 \pm$ & 7.19 \\
\hline & \pm 0.41 & & 33 & 8.61 & 4.73 & \pm 0.03 & \pm 4.95 & 1.50 & \pm 2.91 \\
\hline C-settling & 7.39 & $2282 \pm 5$ & $21 \pm$ & $332.9 \pm 4$ & $4.25 \pm$ & 0.17 & 13.42 & $17.84 \pm$ & 3.79 \\
\hline $\operatorname{tank}$ & \pm 0.55 & 09 & 12 & 9.99 & 3.16 & \pm 0.06 & \pm 5.18 & 2.98 & \pm 0.56 \\
\hline \multirow{2}{*}{ C-effluent } & & $2207 \pm 4$ & $25 \pm$ & $310.9 \pm 3$ & $1.66 \pm$ & 0.06 & 15.49 & $17.21 \pm$ & 3.23 \\
\hline & \pm 0.33 & 44 & 7 & 3.33 & 1.90 & \pm 0.08 & \pm 4.27 & 2.41 & \pm 0.47 \\
\hline \multirow{2}{*}{ D-influent } & 7.59 & $2008 \pm 3$ & 646 & $499.2 \pm 1$ & 79.04 & 0.10 & $1.37 \pm$ & $80.50 \pm$ & 6.04 \\
\hline & \pm 0.1 & 2 & \pm 262 & 22.4 & \pm 10.12 & \pm 0.13 & 0.97 & 9.58 & \pm 1.16 \\
\hline \multirow{2}{*}{ D-OD out } & 7.44 & $1564 \pm 1$ & $46 \pm$ & $361.5 \pm 3$ & $7.21 \pm$ & 0.28 & 15.07 & $22.56 \pm$ & 9.86 \\
\hline & \pm 0.2 & 06 & 25 & 2.99 & 3.15 & \pm 0.37 & \pm 10.54 & 10.26 & \pm 3.04 \\
\hline D-settling & 7.64 & $1515 \pm 7$ & $27 \pm$ & $256.6 \pm 4$ & $5.15 \pm$ & 0.15 & 14.07 & $19.37 \pm$ & 3.10 \\
\hline tank & \pm 0.53 & 8 & 11 & 4.89 & 3.68 & \pm 0.09 & \pm 10.09 & 6.46 & \pm 1.30 \\
\hline \multirow{2}{*}{ D-effluent } & 7.49 & $1518 \pm 9$ & $23 \pm$ & $261.7 \pm 3$ & $4.59 \pm$ & 0.20 & 13.39 & $18.17 \pm$ & 3.33 \\
\hline & \pm 0.3 & 1 & 13 & 3.33 & 3.25 & \pm 0.10 & \pm 9.68 & 6.86 & \pm 1.36 \\
\hline \multirow{2}{*}{ E-influent } & 8.07 & $2034 \pm 8$ & 271 & $597.2 \pm 1$ & 76.54 & 0.03 & $0.45 \pm$ & $77.02 \pm$ & 5.49 \\
\hline & \pm 0.55 & 7 & \pm 58 & 6.68 & \pm 5.54 & \pm 0.04 & 0.52 & 5.85 & \pm 0.82 \\
\hline E-Primary & 8.07 & $2040 \pm 6$ & 196 & $700.3 \pm 6$ & 67.84 & 0.07 & $0.04 \pm$ & $67.94 \pm$ & 5.80 \\
\hline settling & \pm 0.53 & 1 & \pm 59 & 0.33 & \pm 11.22 & \pm 0.08 & 0.02 & 11.28 & \pm 1.05 \\
\hline
\end{tabular}




\begin{tabular}{|c|c|c|c|c|c|c|c|c|c|}
\hline \multicolumn{10}{|l|}{ E- } \\
\hline Anaerobic & 7.67 & $1821 \pm 3$ & $99 \pm$ & $546.5 \pm 1$ & 31.38 & 0.55 & $0.64 \pm$ & $32.57 \pm$ & 9.53 \\
\hline out & \pm 0.42 & 9 & 36 & 22.5 & \pm 5.99 & \pm 0.67 & 0.75 & 5.66 & \pm 2.04 \\
\hline E-Anoxic & 7.51 & $1692 \pm 9$ & 174 & $487.3 \pm 5$ & 19.27 & 0.60 & $0.38 \pm$ & $20.24 \pm$ & 10.2 \\
\hline out & \pm 0.43 & 7 & \pm 37 & 1.09 & \pm 5.93 & \pm 0.57 & 0.22 & 5.17 & $4 \pm 3.79$ \\
\hline \multirow{2}{*}{ E-Oxic out } & 7.33 & $1589 \pm 6$ & $84 \pm$ & $414.9 \pm 6$ & $5.39 \pm$ & 0.34 & $7.07 \pm$ & $12.79 \pm$ & 3 \\
\hline & \pm 0.55 & 9 & 14 & 2.94 & 3.78 & \pm 0.41 & 4.02 & 1.81 & \pm 2.6 \\
\hline \multicolumn{10}{|l|}{ E- } \\
\hline Secondary & 7.43 & $1599 \pm 5$ & $24 \pm$ & $264.3 \pm 1$ & $0.95 \pm$ & 0.97 & 31.43 & $33.34 \pm$ & 6.01 \\
\hline settling & \pm 0.69 & 1 & 7 & 7.15 & 0.93 & \pm 0.57 & \pm 4.85 & 4.12 & \pm 1.25 \\
\hline \multicolumn{10}{|l|}{ E- } \\
\hline Secondary & 7.64 & $1606 \pm 6$ & $30 \pm$ & $255.5 \pm 1$ & $0.96 \pm$ & 0.85 & 31.47 & $33.28 \pm$ & 4.88 \\
\hline effluent & \pm 0.75 & 3 & 2 & 9.03 & 0.83 & \pm 0.61 & \pm 5.05 & 4.52 & \pm 0.33 \\
\hline E-Tertiary & 8.23 & $1476 \pm 2$ & $16 \pm$ & $97.3 \pm 27$ & $0.58 \pm$ & 0.19 & $30.4 \pm$ & $31.17 \pm$ & 1.12 \\
\hline effluent & \pm 0.34 & 3 & 5 & .3 & 0.79 & \pm 0.13 & 5.16 & 5.04 & \pm 0.35 \\
\hline F-infl & 7.77 & $3415 \pm 7$ & 137 & $446.8 \pm 1$ & 32.96 & 4.02 & $1.06 \pm$ & $38.04 \pm$ & 0.81 \\
\hline 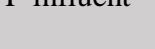 & \pm 0.33 & 75 & \pm 16 & 5.75 & \pm 2.81 & \pm 3.18 & 0.42 & 5.56 & \pm 0.18 \\
\hline F-Primary & 7.81 & $2755 \pm 3$ & 104 & $450.7 \pm 2$ & 37.74 & $0.7 \pm$ & $1.25 \pm$ & $39.69 \pm$ & 0.49 \\
\hline settling & \pm 0.31 & 55 & \pm 29 & 1.68 & \pm 6.76 & 0.88 & 1.27 & 5.12 & \pm 0.30 \\
\hline \multicolumn{10}{|l|}{ F- } \\
\hline Anaerobic & 7.44 & $2530 \pm 2$ & 126 & $434.6 \pm 7$ & 21.23 & 0.77 & $7.73 \pm$ & $29.72 \pm$ & $0.8 \pm$ \\
\hline out & \pm 0.33 & 10 & \pm 36 & 1.93 & \pm 3.25 & \pm 0.82 & 3.38 & 4.12 & 0.45 \\
\hline F-Anoxic & $7.3 \pm$ & $2475 \pm 1$ & 141 & $364.5 \pm 6$ & 15.58 & 0.21 & 14.43 & $30.22 \pm$ & 1.18 \\
\hline out & 0.52 & 85 & \pm 37 & 2.85 & \pm 10.59 & \pm 0.20 & \pm 10.7 & 1.12 & \pm 0.89 \\
\hline$F_{-} O x$ & 6.82 & $2480 \pm 1$ & $81 \pm$ & $337.7 \pm 7$ & $6.07 \pm$ & $0.9 \pm$ & 17.16 & $24.13 \pm$ & 0.67 \\
\hline & \pm 0.25 & 80 & 36 & 1.21 & 5.39 & 0.97 & \pm 9.43 & 6.3 & \pm 0.32 \\
\hline \multicolumn{10}{|l|}{ F- } \\
\hline Secondary & 7.44 & $2560 \pm 1$ & $36 \pm$ & $214.7 \pm 4$ & $3.69 \pm$ & 0.05 & 34.93 & $38.67 \pm$ & 0.58 \\
\hline settling & \pm 0.6 & 40 & 22 & 2.08 & 4.94 & \pm 0.04 & \pm 7.01 & 2.25 & \pm 0.27 \\
\hline \multicolumn{10}{|l|}{ F- } \\
\hline Secondary & 7.44 & $2565 \pm 1$ & $26 \pm$ & $194.5 \pm 3$ & $0.8 \pm 0$ & 0.04 & $36.8 \pm$ & $37.64 \pm$ & 0.85 \\
\hline effluent & \pm 0.6 & 25 & 12 & 6.9 & .77 & \pm 0.02 & 4.03 & 3.24 & \pm 0.83 \\
\hline F-Tertiary & 7.41 & $2580 \pm 1$ & $23 \pm$ & $191.2 \pm 3$ & $0.84 \pm$ & 0.09 & 38.42 & $39.35 \pm$ & 0.36 \\
\hline settling & \pm 0.47 & 20 & 11 & 7.53 & 0.89 & \pm 0.09 & \pm 5.06 & 4.1 & \pm 0.08 \\
\hline F-Tertiary & 7.43 & $2580 \pm 1$ & $25 \pm$ & $186.8 \pm 2$ & $0.86 \pm$ & 0.04 & 37.47 & $38.37 \pm$ & $0.2 \pm$ \\
\hline effluent & \pm 0.51 & 30 & 10 & 7.74 & 0.86 & \pm 0.03 & \pm 4.18 & 3.41 & 0.16 \\
\hline
\end{tabular}


Table 2 Multiple linear regression models for ARGs in wastewater.

\begin{tabular}{|c|c|c|c|c|c|}
\hline \multirow{2}{*}{$\begin{array}{l}\text { Absolute abundance of ARG } \\
\qquad\left(\log \text { copies } \cdot \mathrm{g}^{-1}\right)\end{array}$} & \multirow{2}{*}{ Multiple linear regression models } & \multirow{2}{*}{$p$ Value $^{\mathrm{a}}$} & \multirow{2}{*}{$\begin{array}{c}\text { Interpretation of } \\
\text { models }(\%)\end{array}$} & \multicolumn{2}{|c|}{ Interpretation of factors in variation of ARG (\%) } \\
\hline & & & & Factors & Interpretation $(\%)$ \\
\hline bla Тем & $b l a$ TEM $=-3.797+1.21916 \mathrm{~S}$ rRNA & 0.000 & 97.7 & 16S rRNA & 97.7 \\
\hline \multirow[t]{2}{*}{ bla $a_{\text {СТX-M }}$} & bla $_{\text {СТХ-M }}=-5.838+1.13016 \mathrm{~S}$ rRNA $+2.39 \times 10^{-4}$ Chao1 & 0.000 & 96.3 & 16S rRNA & 96.3 \\
\hline & & & & 16S rRNA, Chao1 & 97.4 \\
\hline \multirow[t]{4}{*}{ erm $\mathrm{B}$} & $\operatorname{erm} \mathrm{B}=-0.117+1.029 \operatorname{Tn} 916 / 1545-0.062$ Coord 1 & 0.000 & 99.7 & $\operatorname{Tn} 916 / 1545$ & 98.5 \\
\hline & +0.108 Coord $6+1.24 \times 10^{-4}$ Conductivity & & & Tn916/1545, Coord1 & 99.2 \\
\hline & & & & Tn916/1545, Coord1, Coord6 & 99.4 \\
\hline & & & & Tn916/1545, Coord1, Coord6, Conductivity & 99.7 \\
\hline \multirow[t]{4}{*}{ erm $\mathrm{F}$} & erm $\mathrm{F}=-3.499+1.15316 \mathrm{~S}$ rRNA $-1.86 \times 10^{-4}$ Conductivity & 0.000 & 99.3 & 16S rRNA & 97.0 \\
\hline & $+0.172 \mathrm{NO}_{2}^{-}-\mathrm{N}+0.089 \mathrm{PO}_{4}^{3-}-\mathrm{P}$ & & & 16S rRNA, Conductivity & 98.0 \\
\hline & & & & $16 \mathrm{~S}$ rRNA, Conductivity, $\mathrm{NO}_{2}^{-}-\mathrm{N}$ & 98.5 \\
\hline & & & & $16 \mathrm{~S}$ rRNA, Conductivity, $\mathrm{NO}_{2}^{-}-\mathrm{N}, \mathrm{PO}_{4}^{3-}-\mathrm{P}$ & 99.1 \\
\hline \multirow[t]{3}{*}{$m e f \mathrm{~A} / \mathrm{E}$} & $m e f \mathrm{~A} / \mathrm{E}=-0.720+1.092 \operatorname{Tn} 916 / 1545+2.00 \times 10^{-4}$ Conductivity & 0 & 99.5 & $\operatorname{Tn} 916 / 1545$ & 98.4 \\
\hline & +0.116 Coord 6 & & & Tn916/1545, Conductivity & 98.9 \\
\hline & & & & Tn916/1545, Conductivity, Coord6 & 99.4 \\
\hline \multirow[t]{2}{*}{$q n r \mathrm{~A}$} & $q n r \mathrm{~A}=-0.243+0.571$ int $11+4.55 \times 10^{-4}$ Conductivity & 0.000 & 88.2 & intI1 & 77.4 \\
\hline & & & & int 11 , Conductivity & 88.2 \\
\hline \multirow[t]{3}{*}{$q n r \mathrm{~S}$} & $q n r \mathrm{~S}=1.444+0.450$ int $I 1+3.74 \times 10^{-4}$ Conductivity $+0.020 \mathrm{TN}$ & 0.000 & 93.2 & intI1 & 83.8 \\
\hline & & & & int 11 , Conductivity & 88.2 \\
\hline & & & & int $I 1$, Conductivity, TN & 93.2 \\
\hline \multirow[t]{3}{*}{ Total ARGs } & Total ARGs $=12.213+8.02516 \mathrm{~S}$ rRNA $-5.202 \mathrm{pH}-0.628$ Coord 1 & 0.000 & 99.7 & 16S rRNA & 98.6 \\
\hline & & & & 16S rRNA, pH & 99.2 \\
\hline & & & & $16 \mathrm{~S}$ rRNA, pH, Coord 1 & 99.7 \\
\hline
\end{tabular}

Note: $\mathrm{a}-p$ value for the F-test. A $p$ value $<0.05$ indicates that the multiple linear regression model is statistically significant. 
Table 3 Multiple linear regression models for ARGs in sludge.

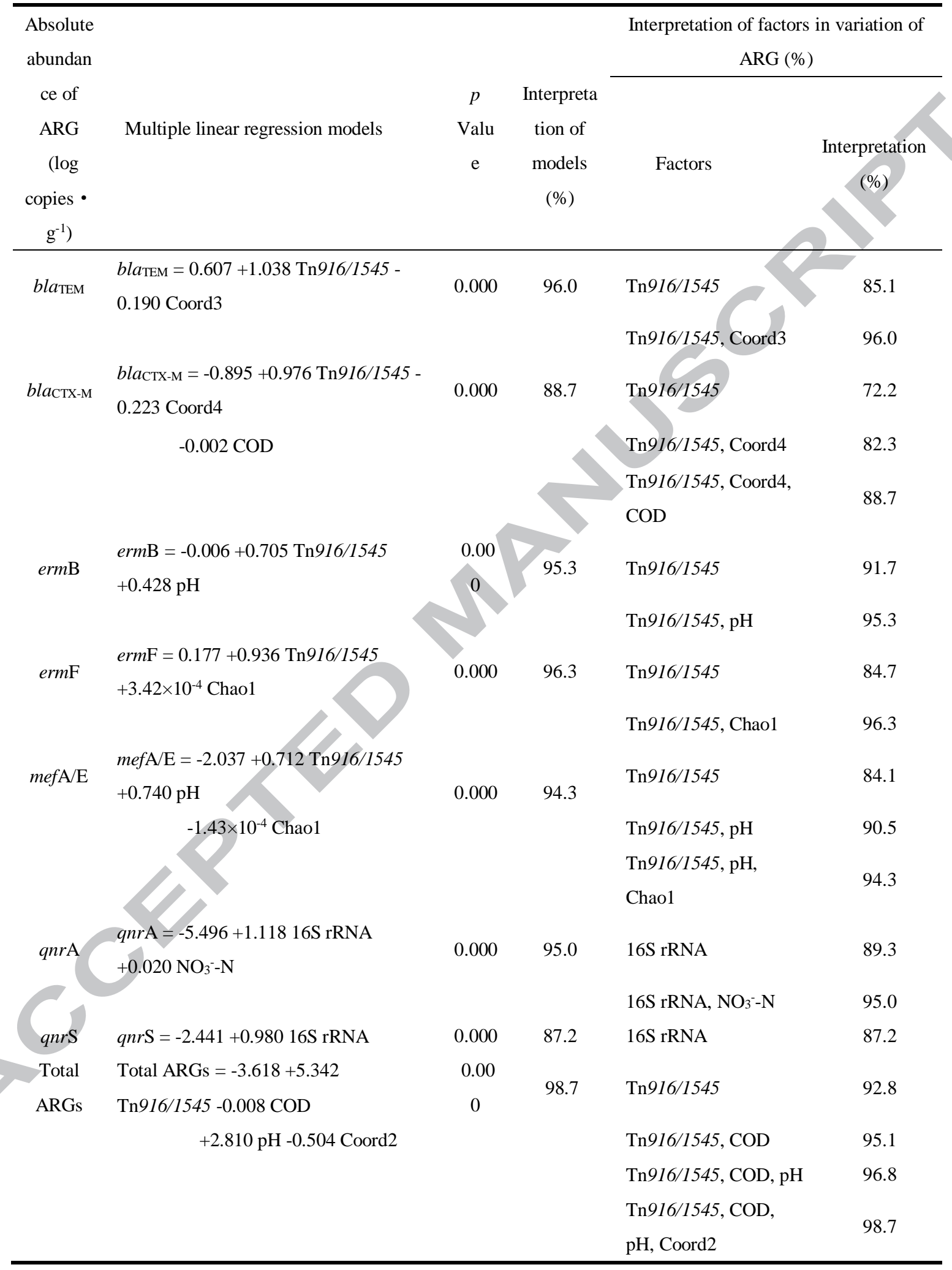




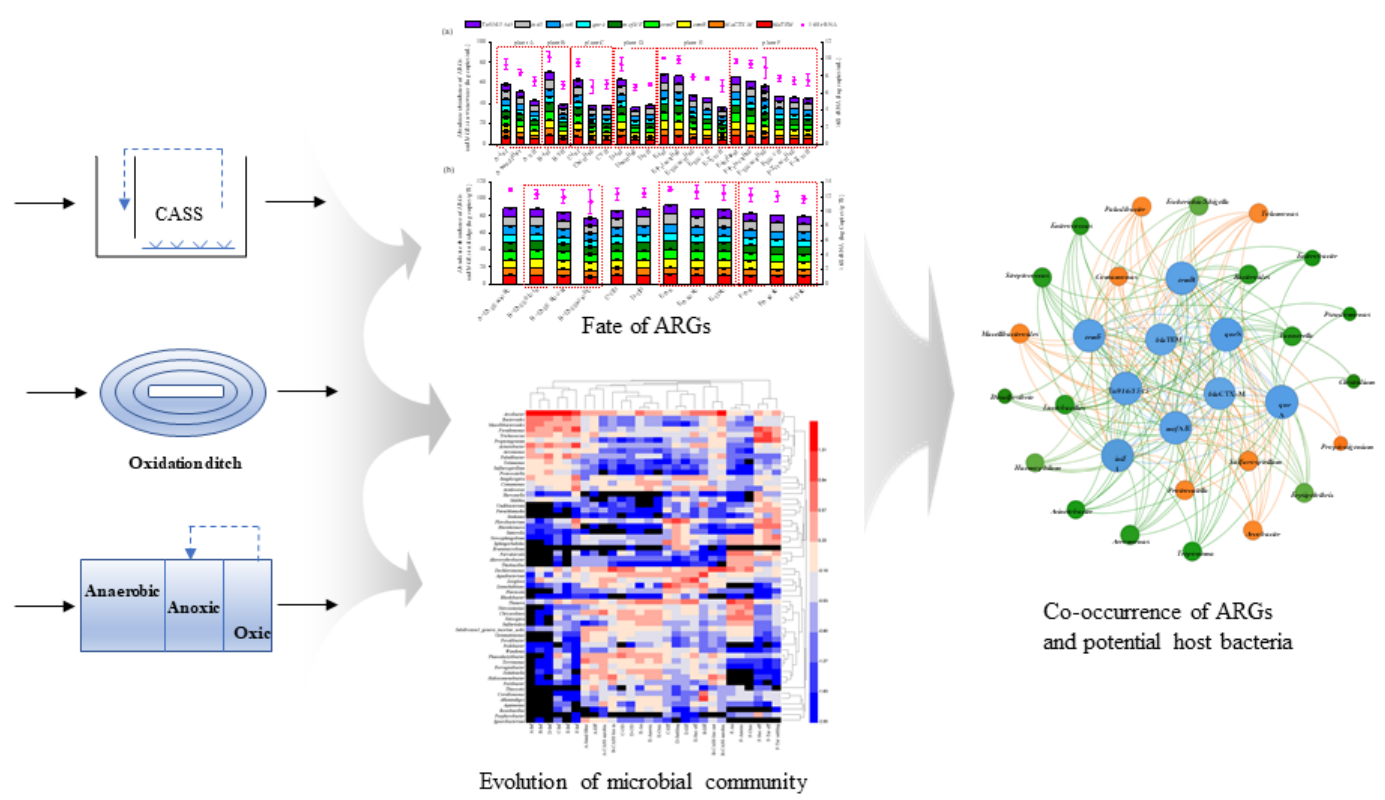




\section{Highlights}

- Similar influents in varied processes lead to similar sludge microbial community.

- HGT might mainly occur in an aeration tank rather than the anaerobic/anoxic tank.

- Higher co-occurrence of potential pathogens and ARGs in wastewater than in sludge.

- Microbial biomass mainly drive ARGs in wastewater, while MGEs drive ARGs in sludge.

- Enhancement in nutrients removal and tertiary treatment would benefit ARGs removal. 